
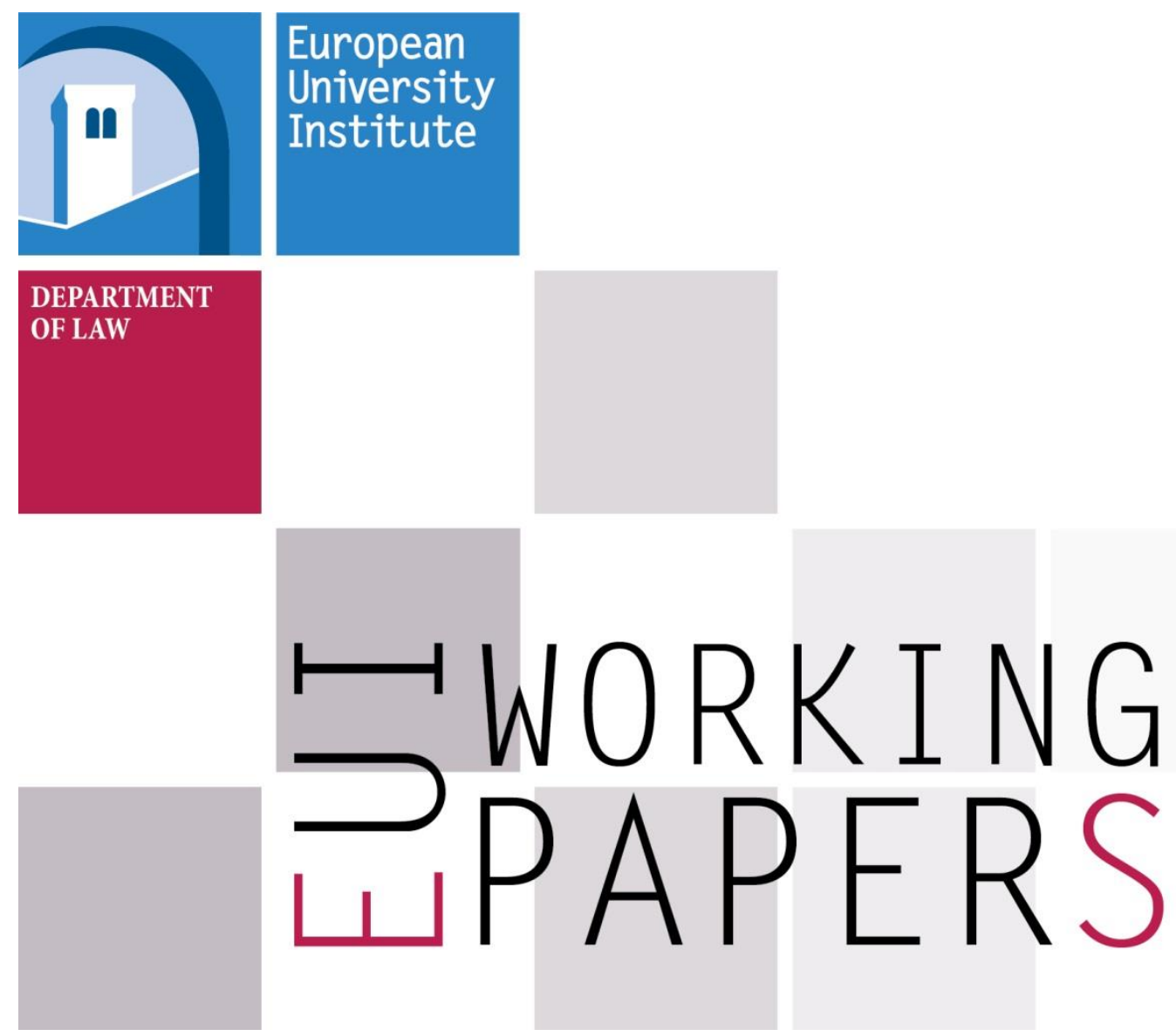

LAW 2016/02

Department of Law

Human rights law in international investment arbitration

Vivian Kube and Ernst-Ulrich Petersmann 

European University Institute Department of Law

\section{HUMAN RIGHTS LAW IN INTERNATIONAL INVESTMENT ARbitration}

Vivian Kube and Ernst-Ulrich Petersmann

EUI Working Paper LAW 2016/02 
This text may be downloaded for personal research purposes only. Any additional reproduction for other purposes, whether in hard copy or electronically, requires the consent of the authors. If cited or quoted, reference should be made to the full name of the authors, the title, the working paper or other series, the year, and the publisher.

ISSN 1725-6739

(C) Vivian Kube and Ernst-Ulrich Petersmann, 2016

Printed in Italy

European University Institute

Badia Fiesolana

I-50014 San Domenico di Fiesole (FI)

Italy

www.eui.eu

cadmus.eui.eu 


\begin{abstract}
Parts I-III of this paper give an overview of references to human rights - mainly at the initiative of host states and non-governmental third parties, but increasingly also by complainants and judges on their own initiative - in international investment disputes and investor-state arbitral awards and the responses by investment tribunals to such human rights arguments. They discuss the problems of 'legal fragmentation' of international investment law and human rights law, the need for judicial balancing of state-centered 'principles of justice' (like state responsibility) and person-oriented principles of justice (such as human rights and 'proportionality balancing') in trade and investment disputes, and related problems of legal methodology. Part IV concludes with a brief discussion of the increasing impact of the human rights obligations of all UN member states on investment disputes in other international courts and in private commercial arbitration, for instance due to the UN Guiding Principles on Business and Human Rights and their approval and increasing incorporation by thousands of transnational corporations and non-governmental organizations (like the International Federation of Football Associations) into their commercial contract practices.
\end{abstract}

\title{
Keywords
}

human rights; investment law; investor-state arbitration; judicial comity; legal methodology; principles of justice; treaty interpretation. 



\section{Table of contents}

\section{INTRODUCTION: FROM FRAGMENTATION TOWARDS INTEGRATION OF HUMAN RIGHTS}

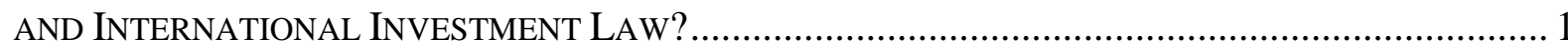

The Role of Arbitrators: Approaches to Human Rights ARgumentATION IN ISDS ...... 4

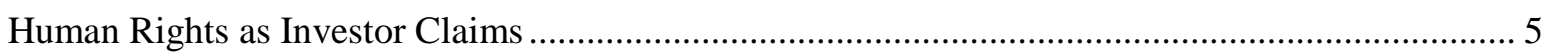

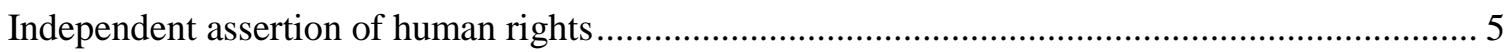

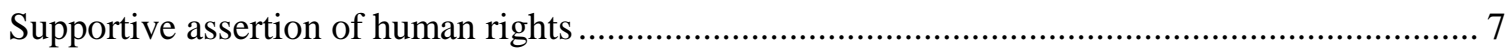

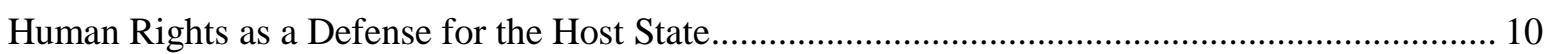

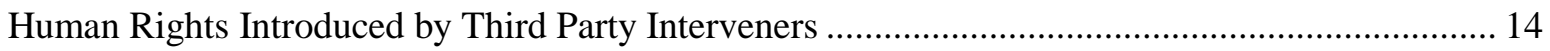

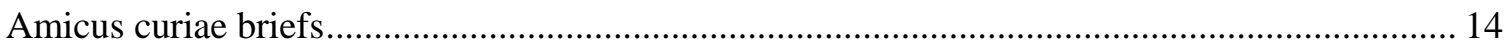

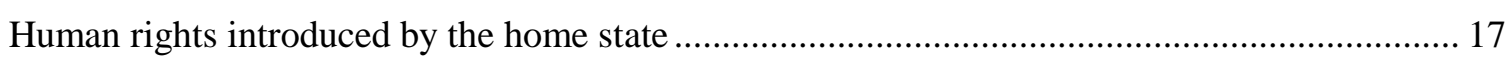

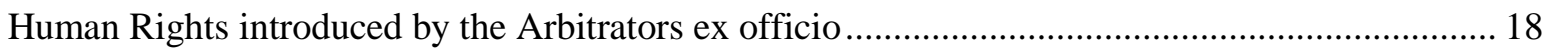

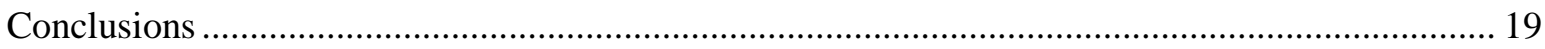

The Role of the Law: Methodology Questions Regarding the Human Rights

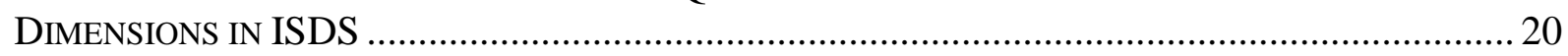

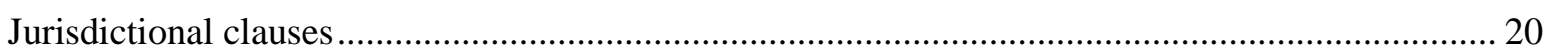

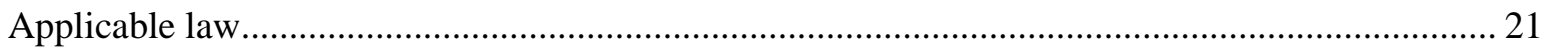

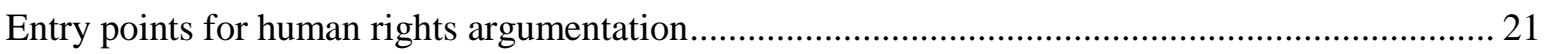

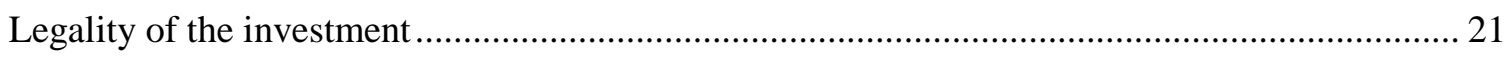

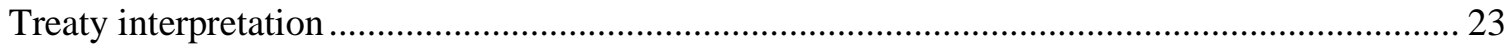

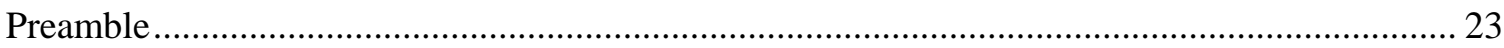

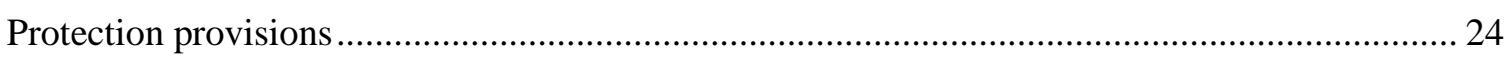

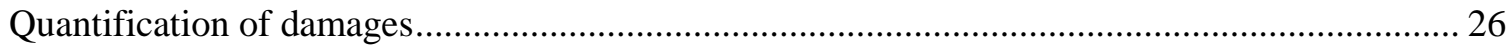

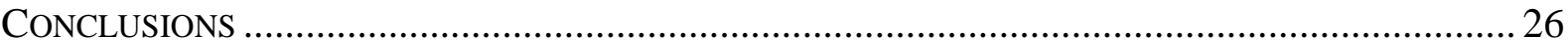





\section{Introduction: From Fragmentation towards Integration of Human Rights and International Investment Law?}

Most bilateral investment treaties (BITs) and most published investor-state dispute settlement (ISDS) awards continue to be silent on human rights law (HRL). The inclusion of ISDS into modern free trade agreements (FTAs) - like the Canada-EU Comprehensive Economic and Trade Agreement (CETA) and the Trans-Pacific-Partnership (TPP) -, the revision of some model BITs and the increasing number of third party interventions in ISDS are, however, prompting increasing references to HRL, e.g. in the Preamble of the 2014 CETA and in ISDS awards responding to human rights arguments by the complainant, the respondent or in third party interventions. There is also an increasing number of investment-related disputes in regional human rights organizations like the European Court of Human Rights (ECtHR), the Inter-American Court of Human Rights (IACtHR) or the African Human Rights Commission, as well as ISDS awards referring to the proportionality methods used by regional human rights courts. The EU competence for investment regulation since the Lisbon Treaty is likely to lead to replacement of ISDS among the $28 \mathrm{EU}$ member states by new multilevel legal rights and remedies under EU law. This 'constitutionalization' of ISDS among EU countries reflects the concerns of human rights advocates that ISDS provisions between capital-exporting developed countries and lessdeveloped, capital-importing countries were not only designed to protect basic requirements of justice like non-discrimination, fair treatment or prohibition of expropriation without compensation. Since the first modern BIT between Germany and Pakistan in 1959 (which still lacked ISDS provisions), many BITs with ISDS were also concluded with despotic and corrupt governments that disregarded human rights and enriched themselves through collaboration with foreign investors (e.g. in the oil and minerals sector), as documented by civil society complaints to human rights bodies. The civil society perception of systemic bias of ISDS against HRL is one of the main reasons for the civil society opposition to including ISDS into transatlantic FTAs among constitutional democracies with impartial and independent judiciaries committed to protecting constitutional and human rights in nondiscriminatory ways without privileging powerful corporate interests and their constituencies (including the relatively small number of arbitrators from big law firms advising transnational companies (TNCs) and accounting for a large part of ISDS arbitrators). ${ }^{1}$

This opening of ISDS to HRL and European constitutional law reflects the dialectic evolution of national and international legal systems through 'fragmentation' and 'integration' of legal subsystems. ${ }^{2}$ It is increasingly understood that ISDS is not merely concerned with inter partes disputes; the outcome of many cases also impacts on the human rights situation of third party individuals, communities and entire populations. Apart from concrete conflicts within individual cases, studies reveal repercussions of the ISDS system on states' willingness to adopt regulations for human rights advancement that could potentially reduce profits for foreign investors (i.e. the so-called regulatory chill). ${ }^{3}$ Arbitrators - as shapers of international investment law (IIL) and hence as part of a public law system - should be aware of these legal interrelationships.

Is this reality reflected in investment arbitration? Or does refusal of human rights integration lead to a systematic bias perpetuating the institutionalized privilege of investors? How perceptive is investment arbitration of human rights argumentation? This paper seeks to present the current state of integration

\footnotetext{
1 Cf. Ernst-Ulrich Petersmann, "Transformative Transatlantic Free Trade Agreements without Rights and Remedies of Citizens?," JIEL 2015, 579-608.

2 Cf. M.Andenas/E.Bjorge (eds), A Farewell to Fragmentation. Reassertion and Convergence in International Law (CUP 2015).

${ }^{3}$ See, for instance, UN Economic and Social Council, Commission on Human Rights, Economic, Social and Cultural Rights - Human Rights, Trade and Investment, Report of the High Commissioner for Human Rights, 2 July 2003, UN Doc. No. E/CN.4/Sub.2/2003/9, 21.
} 
and acceptance of HRL by ISDS. Besides an analysis of the role of the arbitrators in this integration process with which Part II is concerned, Part III will also briefly look into the role of the law and potential 'entry points' for human rights arguments in the provisions of conventional BITs and International Investment Agreements (IIAs). The aim of looking at human rights integration from these two angles is to understand whether the treaty texts already provide for sufficient tools and human rights integration and, if not, to reveal the main barriers for legal coherence. The paper covers publicly available arbitration awards that are believed to be representative also for the many investorstate arbitration procedures that continue to remain confidential due to the requests of the parties concerned.

Part II assesses arbitral awards in which at least one of the relevant actors (investor, host state, third party interveners and arbitrators ex officio) deployed human rights based argumentation. This part also analyses the possibility of drawing general conclusion on the parameters of accepted and successful human rights argumentations. What kind of human rights are perceived as relevant? Under what circumstances? Whose human rights are protected and whose are ignored? The assessment of these awards seems to indicate the following: Arbitral tribunals are more open towards human rights as due process rights, as methodology and as principles of procedural fairness and balancing than towards a right-based approach - a 'right-based approach' meaning the integration of human rights as an authoritative legal regime consisting of legally enforceable entitlements. The only exception to this general trend remains the right to property. Other substantive human rights, e.g. indigenous rights or the right to water are hardly taken into consideration in substantive terms. This case law assessment seems to indicate that as long as the human rights arguments raised show some overlap with procedural rules of fairness or what has been described as the "shared content ${ }^{4}$, arbitral tribunals seem to be more willing to accept their significance. However, since HRL consists of more than these shared concepts and linkages to principles of fairness and procedural rights and its premise of indivisibility excludes any hierarchy amongst the different human rights, such an approach would not fully prevent incompatibilities with HRL.

Part III traces the legal reasons behind these observations by looking into the entry points for human rights and obstacles for integration as they emerge from the texts of BITs and IIAs. This part demonstrates the possibilities (or even duties) that already exist for arbitrators to take into account human rights as well as the obstacles that human rights argumentation needs to overcome, i.e. the justifications for refusing human rights considerations. Such an analysis can be the starting point for revealing the sources of the perceived reluctance towards the integration of human rights and of the marginal role that HRL as a system of substantive rights plays in IIL. If the shortcomings are the result of textual limitations, adjustment and redrafting by the state parties will be required. If one can argue that alternative outcomes of ISDS disputes are already legally possible and textually justifiable, systemic reform might be necessary - assuming that a structural investor privilege at the expense of human rights compliance is not in the state parties' interest.

The case-studies of arbitral jurisprudence in Part II - and of investment treaty provisions in Part III are part of a broader, systemic problem of international law, i.e. the dialectic and often antagonistic development of fragmented treaty systems like HRL, monetary and financial law, trade law, investment law, environmental law, labour law, health law or migration law. Fragmented evolution of complex legal systems is often inevitable in view of the sovereignty of states, their legal and democratic diversity, and the often different 'rationalities' of legal sub-systems. For instance:

\footnotetext{
${ }^{4}$ Pierre Marie Dupuy and Jorge E. Viñuales have convincingly demonstrated that HRL and IIL do share some fundamental concepts such as non-discrimination, due diligence, procedural fairness and proportionality; see Pierre-Marie Dupuy and Jorge E. Viñuales, "Human Rights and Investment Disciplines: Integration in Progress," in: M. Bungenberg et. al. (eds), International Investment Law (Baden-Baden: Nomos, 2015), 15 et seq.
} 
- State sovereignty and freedom of contract protect strategic self-interests of powerful actors and their 'national interests' in exploiting their power through reciprocal international agreements like BITs.

- Human rights protect the diversity of individual and democratic conceptions of the values and hierarchies of legal systems (e.g. 'monist' vs 'dualist' ordering of the relationships between national and international law, need for balancing the often one-sided focus of BITs on protecting investor rights with public interests as protected by the human rights obligations of all UN member states).

- The particular rationalities of social sub-systems often differ, as illustrated by utilitarian conceptions of IIL and the deontological conceptions of HRL.

Yet, national and international legal systems also require limiting legal fragmentation, for example due to

- the integration principle requiring interpretation of international treaties taking into account 'any relevant rules of international law applicable in the relations between the parties' (Article 31 (3)(c) of the Vienna Convention on the Law of Treaties (VCLT)), including the human rights obligations of all UN member states under general international law and human rights treaties;

- the inalienable and indivisible character of civil, political, economic, social and cultural human rights and related duties to respect, protect and fulfill human rights, which pursue similar goals as IIL (e.g. the common goal of protection of the right to property and of rule of law); and also

- other 'principles of justice' justifying piecemeal reforms of IIL through clarification (e.g. in new BITs, FTAs and ISDS) of sovereign rights and duties to protect public interests as defined by human rights and related 'principles of justice', including

a) principles of procedural justice (e.g. access to justice),

b) distributive justice (e.g. human rights, sovereign equality of states),

c) corrective justice (e.g. compensation),

d) commutative justice (e.g. reciprocal bargains in concession contracts),

e) and equity (e.g. unforeseen emergency situations).

The separate evolution of HRL and IIL through fragmented treaty systems raises numerous methodological questions that remain to be clarified. For instance, the 'consistent interpretation' and 'integration' requirements cannot override BIT provisions (except in case of jus cogens). Yet, as ISDS may take place in competing jurisdictions (like national courts, investment arbitration, regional economic or human rights courts, the ICJ via diplomatic protection of foreign investors), there is need for promoting mutually consistent interpretations through judicial comity among diverse national, regional, worldwide courts and alternative dispute settlement proceedings (e.g. in the WTO and investment arbitration). The frequent use of indeterminate legal concepts and of incompletely theorized' treaty provisions in investment law (like 'fair and equitable treatment') also raises questions of treaty interpretation, as illustrated by the customary law requirement of interpreting treaties and settling related disputes 'in conformity with the principles of justice and international law', including 'human rights and fundamental freedoms for all', as codified in the Preamble and Article 31 VCLT. Do these 'consistent interpretation' requirements and the inherent judicial powers of 'courts of justice' enable judges to avoid conflicts between HRL and IIL? What are the relationships between 'principles of justice' for relations among states (e.g. defining customary law exceptions on 'necessity' of emergency measures narrowly) and citizen-centered 'principles of justice' like human rights and related treaty exceptions to take measures 'necessary' for protecting and reconciling civil, political, economic, social and cultural human rights? 
As further discussed in Part II, investment tribunals increasingly acknowledge that human rights and IIL 'are not inconsistent, contradictory, or mutually exclusive'. The 'causes of action' in most ISDS procedures are limited to investor claims of violations of IIL obligations; the applicable law, however, may include human rights. BITs and ISDS tribunals rarely refer to human rights; yet, the increasing references to human rights in third party submissions (e.g. in case of investments related to public services like supply of water, health services and electricity) contribute to rendering investment arbitrators more aware that the human rights obligations of the host and home states of the investor may be relevant context for interpreting investment law and deciding investor-state disputes. The UN Guiding Principles on 'business and human rights' and the acceptance of 'corporate social responsibility' standards by thousands of transnational corporations clarify that - in addition to 'state duties to protect human rights' - there are 'corporate responsibilities to respect human rights' and to provide access to effective remedies which increasingly influence international commercial law and arbitration. $^{6}$

\section{The Role of Arbitrators: Approaches to Human Rights Argumentation in ISDS}

This part gives an overview of the approaches adopted by arbitral tribunals when confronted with human rights argumentation. The role of human rights for the investment dispute and the kind of human rights referred vary depending on the actor who introduces them into the dispute. Potentially, these can be investors, home and host states, amici curiae and the arbitrators themselves. Investors as claimants have introduced human rights argumentation as either independent claims next to the violations of BIT rights or in support of the alleged violation of a BIT (e.g. to substantiate a certain interpretation of treaty terms such as expropriation). Host states have occasionally invoked human rights as respondents to justify state action that allegedly led to an investor right violation. The success of such defense hinges on whether the objective of a measure plays a role for determining the existence of breach or whether the severity and the impact on the investor are the decisive criteria. Furthermore, 'counterclaims' brought forward by the respondent state which address the investors' conduct can also potentially be based on human rights argumentation. ${ }^{7}$ This could, for example, be the case, when the investor was either obliged to human rights compliance under a contract or the establishment and/or operation of an investment violated local and/or international laws that incorporates human rights duties for the private sector. Increasingly civil society organizations, NGO's and public interest lawyers have sought allowance to intervene as amici aiming for raising awareness to human rights concerns. In theory, if the procedural rules are formulated sufficiently broad, also home states could intervene as third parties and bring in human rights (possibly to comply with their own obligations to protect human rights). Finally, arbitrators have occasionally referred to human rights methodology ex officio in their reasoning. The following part will survey the ISDS jurisprudence categorized by the different actors in order to distill what kind of human rights are introduced, what kind of approaches are adopted, and what impact human rights based argumentation has on the decision making. The cases analyzed below are limited to the most prominent and most

5 Suez, Sociedad General de Aguas de Barcelona, S.A. and Vivendi Universal, S.A. v. Argentina, ICSID ARB/03/19, Decision on Liability, 30 July 2010, para. 262; Hulley Enterprises Limited (Cyprus) v. The Russian Federation, PCA Case No. AA 226, Yukos Universal Limited (Isle of Man) v. The Russian Federation, PCA Case No. AA 227, Quasar de Valors SICAV S.A. et al. (Formerly Renta 4 S.V.S.A et al.) v. Russian Federation, SCC Case No. 24/2007, Award, 20 July 2012, Veteran Petroleum Limited (Cyprus) v. Russian Federation, PCA Case No. AA 228, Final Award, 18 July 2014; ECtHR, OAO Neftyanaya Kompaniya Yukos v. Russia, Application no. 14902/04, Judgment, 20 September 2011.

${ }^{6}$ Cf. J.G.Ruggie/J.F.Sherman III, Adding Human Rights Punch to the New Lex Mercatoria: The Impact of the UN Guiding Principles on Business and Human Rights on Commercial Legal Practice, in: Journal of Int'l Dispute Settlement 6 (2015), 455-461.

${ }^{7}$ Counterclaims is not used in a technical sense, meaning a separate claim seeking independent affirmative relief, but in the sense of a further argument against the existence of a treaty breach. Whether investment tribunals have jurisdiction over proper counterclaims depends on the phrasing of the jurisdictional clause. 
recent cases. Apart from offering an analysis of the most recent and less discussed cases, this contribution aims to also provide new perspectives on the 'classic' arbitral awards.

\section{Human Rights as Investor Claims}

First, human rights arguments can be introduced into ISDS by the usual initiator of investment disputes: the investor as the complainant. In fact, investors have strategically engaged in human rights argumentation both by basing their claims directly on human rights violations in addition to breaches of IIA provisions (independent assertion of human rights) and as support for establishing a Treaty breach by deriving favorable methodology or arguments from HRL and jurisprudence (supportive assertion of human rights).

\section{Independent assertion of human rights}

Intuitively, investment tribunals may seem to be a rather odd place for independent human rights claims since the tribunals constituted under an IIA have a limited mandate and not the expertise and legitimacy of an official human rights body. Nevertheless, if the jurisdictional and applicable law clauses of the respective IIA are sufficiently broad to include human rights violations, adjudicating a pure human rights claim could be possible.

In Biloune v Ghana $^{8}$, a Syrian investor based his claim on violations of human rights (namely arbitrary detention and deportation) besides contractual breaches of an agreement between him and Ghana. The tribunal declared that it lacked jurisdiction to rule on human rights issues as an independent cause of action. This conclusion was based on the jurisdictional clause in the agreement, according to which arbitration only covers disputes arising 'in respect of the enterprise'. ${ }^{9}$ Interestingly, the actions alleged to be human rights violations were nevertheless taken into consideration when deciding on expropriation. The relation was deemed sufficient for factoring it in when determining the severity of the intrusion that precisely for that reason was found to be tantamount to expropriation. ${ }^{10}$ This may indicate that although the tribunal was reluctant to directly adjudicate on human rights, the fact that the governmental action had severe consequences for the individual could not be ignored (and was thus brought to bear in the determination of expropriation).

In Chevron v Ecuador I, an independent assertion of denial of justice as a principle of customary law was accepted at the jurisdictional stage. ${ }^{11}$ The tribunal stressed that the only requirement for jurisdiction stipulated by the jurisdictional clause is sufficient relation to the investment; it found this requirement to be satisfied. Contrary to the Biloune assessment, this tribunal concluded that claims based on international customary law fall under the purview of the jurisdictional clause also as independent causes of action provided that the claims constitute an 'investment dispute'. As the definition of investment was interpreted broadly, such a relation was not difficult to establish. Adopting the Mondev approach, the tribunal declared that lawsuits fall within the definition of investment if they are part of the 'overall investment project'. ${ }^{12}$ It argued that the non-exhaustive list

\footnotetext{
${ }^{8}$ Biloune and Marine Drive Complex Ltd v. Ghana Investments Centre and the Government of Ghana, Award Jurisdiction and Liability, 27 October 1989, 95 ILR 184.

${ }^{9}$ According to the arbitration clause in the Ghana Investment Centre (GIC) Agreement, arbitration covers disputes arising "in respect of the enterprise"; Biloune v. Ghana Investments Centre and the Government of Ghana, Award. 27 October 1989 and 30 June 1990, YCA 1994, 12, 13.

${ }^{10}$ Biloune v. Ghana Investments Centre and the Government of Ghana, 209 - 210.

11 Chevron Corporation (USA) and Texaco Petroleum Corporation (USA) v Ecuador, UNCITRAL, Interim Award, 1 December 2008, paras 2, 3 .

12 Ibid. para. 180.
} 
of possible forms of an investment included in the definition in the treaty demonstrated this provision's purpose of closing any possible gaps of protection that may arise when the initial investment assumes different shapes over time. ${ }^{13}$

For both tribunals, jurisdiction over the claim depended on the relation between a violation of human rights (or the customary law prohibition of denial of justice) and the investment. Most jurisdictional clauses are phrased along similar lines. Nevertheless, considering these two different outcomes, it is difficult to derive any generally applicable standards regarding independent human rights claims. In Chevron v Ecuador I, the claimant referred to specific human rights obligations of Ecuador under the American Convention on Human Rights (ACHR) in conjunction with a BIT clause providing for no lesser treatment than required by international $\mathrm{law}^{14}$; the claimant further referred to jurisprudence of the IACtHR and of the ECtHR in order to determine what constitutes an undue delay of proceedings. The tribunal declared the denial of justice provisions in the BIT as lex specialis; there was thus no need for recourse to customary international law. ${ }^{15}$ According to the tribunal, due to their similar genesis, the interpretation of the BIT provision should nevertheless be informed by the international law on denial of justice. ${ }^{16}$ This argumentation allowed the tribunal to legitimately seek guidance by international law while at the same time preserving its discretion as to the concrete application to the given case. The tribunal avoided explicit reference to international law in the subsequent analysis and to the human rights citations of the claimants. Hence, it is impossible to trace the precise impact of the human rights argumentation of the investor on the arbitral award.

In Toto $v$ Lebanon, ${ }^{17}$ the claimant referred to specific human rights in relation to the right to fair trial. ${ }^{18}$ Since the BIT clearly stated that the jurisdiction as well as applicable law covers principles of international law, the tribunal accepted and engaged with the human rights argumentation. ${ }^{19}$ Further, the tribunal explicitly discussed which human rights were applicable to Lebanon (i.e. Article 14 of the International Covenant on Civil and Political Rights (ICCPR) in conjunction with the interpretation of the ICCPR Commission). ${ }^{20}$ It finally refused jurisdiction due to a lack of evidence presented by the claimant. Contrary to the 'interpretative-guidance-approach' in Chevron v Ecuador, it seemed that human rights could have entered the merit stage as rights derived from an independent and relevant body of law. The Toto $v$ Libanon tribunal appeared to be in principle open towards considering human rights as independent claims.

In Roussalis $v$ Romania, the Claimant based the claim on the right to property of Article 1 of the First Additional Protocol to the European Convention on Human Right (ECHR) in addition to BIT breaches. ${ }^{21}$ The tribunal deemed a discussion of the ECHR rights unnecessary since it was convinced that the BIT conferred more favorable rights. This line of reasoning is in line with the statement in Article 10 of the BIT that international obligations shall only be taken into consideration when more favorable. ${ }^{22}$ Yet, it may result in a higher protection of foreign investor rights while disproportionately neglecting other, competing human rights.

\footnotetext{
${ }^{13}$ Ibid. para. 183.

${ }^{14}$ Chevron Corporation (USA) and Texaco Petroleum Corporation (USA) v Ecuador, UNCITRAL, Partial Awards on the Merits, 30 March 2010, para. 166.

${ }^{15}$ Ibid. para. 242 et seq.

${ }^{16}$ Ibid. para. 244.

${ }^{17}$ Toto Costruzioni Generali S.p.A. v. The Republic of Lebanon, ICSID Case No. ARB/07/12.

${ }^{18}$ Ibid. para 144.

${ }^{19}$ Ibid. para. 154 with further reference to Article 7.3 of the Italy-Lebanon BIT 1997.

${ }^{20}$ Ibid. para. 157 et. seq.

${ }^{21}$ Spyridon Roussalis v. Romania, ICSID Case No. ARB/06/1, 7 Dec 2011, paras. 111 et. seq.

${ }^{22}$ Ibid. para. 310.
} 
Supportive assertion of human rights

In the cases, in which investors refer to human rights in order to support their treaty breach claim, the impact of human rights argumentation very often remains unclear as there is not necessarily the need for an explicit decision at the jurisdictional stage.

In Micula $v$ Romania ${ }^{23}$, the tribunal declared that it will be 'mindful' to Article 15 Universal Declaration of Human Rights (UDHR) when determining the legality of deprivation of nationality. ${ }^{24}$ Nevertheless, in its subsequent analysis the tribunal does not refer to this Article again. It is not clear how Article 15 UDHR influenced the judicial reasoning. Additionally, the tribunal's subsequent rejection of the Nottebohm test rather demonstrated a reserved approach towards international law.

In Grandriver Enterprise v USA, the major investors of Grandriver Enterprise were indigenous people belonging to the First Nations. They argued that for the interpretation of the term investment, as well as the standard of protection under the fair and equitable treatment (FET) provision, human rights specifically those that are jus cogens, customary international law and indigenous peoples' rights - had to be taken into account. ${ }^{25}$ They asserted that indigenous peoples' rights amongst others include the obligation to promote commercial activities of First Nations Members. ${ }^{26}$ The tribunal found itself mandated to take public welfare issues into consideration since the preamble of NAFTA refers to 'the need to preserve the NAFTA Parties' flexibility to safeguard the public welfare.' Further, the tribunal discussed the scope of international indigenous rights and the states' duty to proactive consultation prior to enacting legislation that is affecting indigenous communities. It explicitly criticized the behavior of the US authorities for not being sensitive to the particular position of the claimants as indigenous people and thus not meeting international standards. However, the tribunal concluded that this failure did not constitute a beach of NAFTA as NAFTA does not confer a direct and privileged right of consultation to individual investors. If such a duty to pro-actively consult existed, the Tribunal concluded, it would be a collective right and the claimants failed to sufficiently substantiate that they were the legitimate representatives. The tribunal found that it had no jurisdiction over legal issues concerning the investors' individual statuses as members of the First Nations but only over protection standards accorded to investments as derived from NAFTA. ${ }^{27}$

In UPS $v$ Canada, the claimants invoked labor rights, more precisely collective bargaining rights of the Canada postal workers. ${ }^{28}$ According to UPS' arguments, Canada was violating core labor rights of the International Labor Organization (ILO) ${ }^{29}$, the International Bill of Human Rights as well as customary international law by denying Canada postal workers in rural areas the right to collective bargaining. This constituted a breach of Canada's NAFTA obligation to ensure minimum standard of treatment to foreign investors in accordance with international law because the prohibition of collective bargaining created unfairly low wages and distorted competition. The Canadian Union of Postal Workers and the Council of Canadians filed a petition for amicus submission in which they supported UPS' assessment of the core labor rights violations committed by Canada but at the same time highlighted the paradox of UPS' argumentation: UPS is not the right holder of the workers' right at stake and was not truly interested in their enforcement. The latter was demonstrated by UPS'

\footnotetext{
${ }^{23}$ loan Micula, Viorel Micula, S.C. European Food S.A, S.C. Starmill S.R.L. and S.C. Multipack S.R.L. v. Romania, Decision on Jurisdiction, 24 September 2008.

${ }^{24}$ Ibid. para. 88 .

${ }^{25}$ Grand River Enterprises Six Nations, Ltd., et al. v. United States of America, UNCITRAL, Award, 12 January 2013, paras. $66,182$.

${ }^{26}$ Ibid. para 67.

${ }^{27}$ Ibid. para. 220.

${ }^{28}$ United Parcel Services of America, Inc. v. Canada, Investor's Memorial (Merits Phase), 23 March 2005, paras. 645-671.

${ }^{29}$ Freedom of association and the effective recognition of the right to collective bargaining are part of the ILO fundamental conventions (Convention No. 87 and No. 98).
} 
rejection of the affected workers and their representatives as third party interveners. The amici stressed that such rejection was contradictory to the spirit of the very human rights instruments UPS was invoking; for, the latter aimed at workers' empowerment. ${ }^{30}$ It would thus not render Canada's conduct compatible with human rights if the affected individuals remained excluded from the proceedings and negotiations and if only pecuniary damages were awarded to a third party instead of improving the situation for the victims. The tribunal responded neither to this paradox pointed out by the amici nor to other human rights arguments brought forward by the parties. The linkage of national treatment with the workers' rights violations as argued by UPS was rejected without any further explanation. ${ }^{31}$ This case demonstrates how investment arbitration can become the arena for diverse human rights argumentation by all parties. Investment tribunals need to be legally capable of adequately reacting to such human rights arguments.

The investment arbitrations following Russia's criminal proceedings against its biggest and most successful oil company Yukos and its management for tax evasion ${ }^{32}$ and the parallel human rights complaints before the $\mathrm{ECtHR}^{33}$ reveal the diverging concepts of property between human right law and IIL. Since Russia as well as the claimants invoked the ECtHR jurisprudence each in support of their arguments, the tribunals were compelled to find ways to overcome this legal disparity. The tribunals in Quasar de Valors SICAV S.A. v. Russia and Veteran Petroleum v. Russia denied any binding force of the ECtHR's jurisprudence on the tribunals, yet accepted to take them into consideration when needed. In Quasar de Valors SICAV S.A. v. Russia, for instance, the tribunal stressed the differences of the required assessment; unlawfulness or bona fide regulations did not play a role for determining the existence of an expropriation under investor protection law. ${ }^{34}$ The difference between human rights law and investor protection was explained by the fact that the latter was primarily aimed at inducing foreign investment and foreign investors may not benefit from national human rights regulation. ${ }^{35}$ Even though the assessments of the ECtHR did not have any legal force for the particular proceedings, the tribunal was nevertheless entitled to discuss the arguments brought forward before the ECtHR. ${ }^{36}$ In Veteran Petroleum v. Russia, Russia invoked res judicata as a ground for lack of jurisdiction by pointing to the ECtHR proceeding. ${ }^{37}$ The tribunal responded by stating that it was not a human rights court; it would assess the alleged human rights violations of the individuals linked to Yukos as 'part of the factual matrix of the claimants' complaints that the Russian Federation violated its obligations under the ECT ${ }^{38}$ Again, no legal force was ascribed to ECtHR judgment for the arbitration proceedings; yet, the human rights violations played a role in the different assessment of violations of the Energy Charter Treaty.

In Hesham Talaat M. Al-Warraq v. Indonesia, the claimant argued that the term 'basic rights' used in the investment agreement must include human rights; he engaged in an in-depth analysis of the presumption of innocence as recognized in several human rights instruments and the corresponding

\footnotetext{
${ }^{30}$ United Parcel Services of America, Inc. v. Canada, Application for Amicus Curiae Status by the Canadian Union of Postal Workers and the Council of Canadians, 20 October 2005, paras. 36, 58.

${ }^{31}$ United Parcel Services of America, Inc. v. Canada, Awards on the Merits, 24 May 2007, paras. 185 et. seq.

${ }^{32}$ Hulley Enterprises Limited (Cyprus) v. The Russian Federation, PCA Case No. AA 226, Yukos Universal Limited (Isle of Man) v. The Russian Federation, PCA Case No. AA 227, Quasar de Valors SICAV S.A. et al. (Formerly Renta 4 S.V.S.A et al.) v. Russian Federation, SCC Case No. 24/2007, Award, 20 July 2012, Veteran Petroleum Limited (Cyprus) v. Russian Federation, PCA Case No. AA 228, Final Award, 18 July 2014.

${ }^{33}$ ECtHR, OAO Neftyanaya Kompaniya Yukos v. Russia, Application no. 14902/04, Judgment, 20 September 2011.

${ }^{34}$ Quasar de Valors SICAV S.A. et al. (Formerly Renta 4 S.V.S.A et al.) v. Russian Federation, SCC Case No. 24/2007, Award, 20 July 2012, paras 21 et seq, 42 et seq

${ }^{35}$ Ibid. paras 22, 23.

${ }^{36}$ Ibid. para. 24.

${ }^{37}$ Veteran Petroleum Limited (Cyprus) v. Russian Federation, PCA Case No. AA 228, Final Award, 18 July 2014, para. 76.

${ }^{38}$ Veteran Petroleum Limited (Cyprus) v. Russian Federation, PCA Case No. AA 228, Final Award, 18 July 2014, para. 765.
} 
jurisprudence. ${ }^{39}$ The tribunal, however, followed the respondent state by interpreting the term in the specific context of the treaty provision, which is concerned with ownership rights. It discussed the ICCPR and its relevance to the claimant's FET claim as a basic minimum standard; it also examined the scope of Indonesia's obligations, in particular, to comply with the right to be present at trial, to defend oneself and the presumption of innocence. Although the alleged human rights violation could not have constituted a treaty breach in itself, the assessment of the FET principle was in fact mainly an examination of Indonesia's human rights obligations.

In Rompetrol. v. Romania, the investors invoked due process rights under international law as an independent claim and in support of breaches of the Dutch-Romanian BIT and the Energy Charter Treaty (ECT). ${ }^{40}$ The claimants alleged that they had been subject to arbitrary criminal investigations and governmental control measures which amounted to orchestrated state harassment and pressure on the claimant's company in violation of Article 6 ECHR. The parties to the dispute - Romania and Rompetrol - agreed that Article 6 ECHR played a role for the investment dispute; they disagreed as to whether the ECHR standards constituted 'the floor or the ceiling' for protection standards. Romania argued that denial of justice claims should be adjudicated according to the same standards that would apply in any international forum, i.e. higher standards of proof and only after exhaustion of local remedy $;{ }^{41}$ the ECtHR jurisprudence should be considered as the ultimate yardstick for lawful behavior of the investigation authorities. ${ }^{42}$ The arbitral tribunal stressed that the tribunal was established to decide upon legal disputes arising directly out of an investment; the alleged violations of the investors' private lives were not sufficiently related to the investment dispute. Thus, it was not competent to decide on the correct application of the ECHR ${ }^{43}$ However, it did not entirely close the door to recourse to human rights argumentation by stating that it would nevertheless take into account common standards of other international law regimes if appropriate. ${ }^{44}$ Indeed, the tribunal referred back to the ECHR and international norms when assessing the authorities' conduct. Ultimately, the human rights question related to the legality of the criminal proceedings against the individuals linked to Rompetrol, played a role in establishing a breach of the BIT, namely the state's failure to undertake all possible steps within a criminal proceeding to avoid any unnecessarily adverse effect on the investors' interests. ${ }^{45}$

The overview of investor claims based on human rights - either independently or in support of investment law claims - reveals a lack of consistent methodology amongst the legal responses by arbitrators to such human rights claims. In some cases, however, the human rights issues were regarded as so severe or closely linked to the investment that the arbitrators could not ignore their legal relevance. The responses of the arbitrators to the alleged human rights infringements varied from taking them into account in determining a breach of investment law obligations, stating to be 'mindful' or aware of the human rights at stake, to denying the tribunals' competence for examining human rights claims as such. With respect to all of these approaches, the language used remained vague, and the impact of the human rights argumentation is difficult to assess. This lack of judicial methodology in reconciling investor rights with human rights risks entailing biases favoring powerful foreign investors. The reasoning of the Rompetrol tribunal on the need to balance the right to privacy against the public right to information shows that the increased reliance of investors on human rights may

\footnotetext{
${ }^{39}$ Hesham Talaat M. Al-Warraq v. Republic of Indonesia, UNCITRAL, Final Award, 15 December 2014, paras 178 et. seq.

${ }^{40}$ The Rompetrol Group N.V. v. Romania, ICSID Case No. ARB/06/3, Award 6 May 2013, para. 47.

${ }^{41}$ Ibid. para 89.

${ }^{42}$ Ibid. para 83.

${ }^{43}$ Ibid. para 172.

${ }^{44}$ Ibid.

${ }^{45}$ Ibid. para. 279, 280.
} 
compel the ISDS tribunals to discuss the judicial protection of legitimate public policy concerns and competing interests.

\section{Human Rights as a Defense for the Host State}

The host state may rely on human rights argumentation as a respondent of an investor claim. Only very few BITs allow for the host state to initiate proceedings; so far, such complaints do not appear to have happened. ${ }^{46}$ As of yet, human rights have played a role as a justification for state measures undertaken to comply with HRL, i.e. to respect, protect or fulfill human rights independent of whether potential violations are originating in the investor's behavior. For instance, the duty of the state to ensure just and favorable conditions of work may compel states to enact legislation that is to the detriment of the investors' profit. ${ }^{47}$

Human rights can also be invoked as a counterclaim (in the non-technical sense) in relation to investor's misconduct which could justify a denial of benefits. This is, for instance, the case when the investment was initially made in breach of human rights as enshrined in local law and thus does not fall under the purview of an investment definition if such includes an 'in accordance with local law/international law' clause. Also in this case, the host state is in essence invoking its own obligation to prevent violations of human rights on its territory. However, host states often invoke their regulatory discretion without specifying their concrete human rights obligations in investment disputes. Tribunals have recurrently stressed that the objective behind a state measure does not play a role for their assessment of potential BIT breaches. ${ }^{48}$ Even in cases in which a regulation's objective was discussed, the examination tends to focus on general terms - such as 'public/social welfare' or 'public policy ${ }^{, 49}$ - without engaging with concrete human rights obligations of the host state.

One prominent exception are the right to water cases, which illustrate a wide spectrum of possible approaches to human rights justifications. The right to water is part of the $\operatorname{ICESR}^{50}$; it is also recognized in many other human rights treaties and was confirmed in a 2010 UN General Assembly resolution as well as in a 2012 UN Human Rights Council resolution as being part of HRL. ${ }^{51}$ The

${ }^{46}$ Ursula Kriebaum suggests that Article 36 ICSID would allow for such a claim, see Ursula Kriebaum, "Foreign Investments \& Human Rights - The Actors and Their Different Roles”, Transnational Dispute Management 1 (2013): 9.

47 Cf. Article 7 in conjunction with Article 2 of International Covenant on Economic, Social and Cultural Rights ("ICESCR"), adopted and opened for signature, ratification and accession by General Assembly resolution 2200A (XXI) of 16 December 1966, entry into force 3 January 1976.

${ }^{48}$ See, for instance, Compania de Desarrollo de Santa Elena $v$ Costa Rica in which the tribunal noted that '[e]xpropriatory environmental measures - no matter how laudable and beneficial to society as a whole - are, in this respect, similar to any other expropriatory measures that a state may take in order to implement its policies: where property is expropriated, even for environmental purposes, whether domestic or international, the state's obligation to pay compensation remains.' Compania de Desarrollo de Santa Elena SA v Costa Rica, ICSID Case No. ARB/96/1, Award on the Merits, 17 February 2000, para. 72; Also Metalclad v Mexico, ICSID Case No. ARB (AF)/97/1, Award on the Merits, 16 December 2002; Tecnicas Medioambientales Tecmed SA v. Mexico, ICSID Case No ARB (AF)/00/2, Award, 29 May 2003.

${ }^{49}$ See, for instance, Methanex $v$ United States, UNCITRAL Case No. ARB/98/3, Final Award on Jurisdiction and Merits, 3 August 2005, para 312; The Iran-U.S. Claims tribunal recognized a state's right to expropriate for a public purpose when in accordance with due process and non-discriminatory, cf., for instance, Sedco Inc v Iran, 9 Iran-US Claims Tribunal Reports, 248, 275 (1985).

${ }^{50}$ According to General Comment 15 the right to water is part of the right to an adequate standard of living (Article 11), to adequate housing and adequate food (Article 11) and of the highest attainable standard of health (Article 12); Committee on Economic, Social and Cultural Rights, General Comment 15, The right to water, U.N. Doc. E/C.12/2002/11 (2002).

${ }^{51}$ See, for instance, the Convention on the Elimination of All Forms of Discrimination Against Women Article 14, 2(h), Dec. 18, 1979, 1249 U.N.T.S. 13; Convention on the Rights of the Child Article 24, 2(c), Nov. 20, 1989, 1577 U.N.T.S. 3. For an analysis of the different aspects of the human right to water as protected by the different human rights instruments, see: P. Thielbörger, The Right(s) to Water, The Multi-Level Governance of a Unique Human Right, Berlin: Springer, 2014. 
conflicts provoking the investment disputes mainly arose following the privatization of water supply and sewage systems and subsequent termination of concessions or tariff freezing by the states' authorities in order to secure adequate access to water at affordable prices. Although the right to water played a role in the investment disputes as outlined in the following, it was not always the main argument invoked by the host states; it often only played a marginal role in the judicial reasoning.

Especially the early investor claims brought against Argentina demonstrated Argentina's preference for invoking other than human rights justifications. Investors challenged Argentina's emergency measures, which were adopted to mitigate the repercussion of its economic and financial crisis that started in 1999. Many of the emergency measures adopted by Argentina were motivated by the economic and social situation of its population, in particular by the objective of providing affordable access to water and gas. Still, the core of Argentina's argumentation and likewise of the tribunals' assessment was the 'necessity defense'. In Azurix, the tribunal failed 'to understand the incompatibility' with human rights as the facts had not been sufficiently established. ${ }^{52}$ Possibly, Argentina has to be blamed for failing to substantiate the connection between the measures adopted and the protection of the water quality. ${ }^{53}$ In contrast to this outright refusal to consider Argentina's human rights obligations with respect to right to water, the tribunal was not reluctant to follow the Tecmed tribunal and 'seek guidance' in the case-law of the ECtHR for interpreting the scope of property rights and the role that 'public purpose' ought to play for determining expropriation. ${ }^{54}$ With reference to the ECtHR case James and Others, the Tribunal came to the conclusion that the public purpose of a measure plays a less significant role when the affected individual is a non-national. Consequently, there was no discussion on the relation between protection of rights to water as a public purpose and expropriation of foreign investors. Similarly, in Siemens, the human rights relevance was rejected because Argentina failed to develop the argument that state measures to protect the human rights of domestic citizens may justify expropriation of foreign investors without full compensation. ${ }^{55}$

In Suez/Vivendi, the human rights argumentation was substantiated more convincingly. Five NGOs as amici as well as Argentina stressed the importance and the potential risk for the right to water that Argentina aimed to protect by freezing the water tariffs. ${ }^{56}$ The tribunal did not discuss the human rights argumentation when interpreting the substance of investor rights as requested by Argentina and the amici. Only the exceptional circumstances of the crisis were considered relevant for the FET standard. In that context the tribunal acknowledged that safeguarding sufficient water supply "was vital for the health and well-being of 10 million people". ${ }^{57}$ Nevertheless, it concluded that adopting measures in breach of investors' rights were not the only means available. The tribunal stated that human rights obligations as well as BIT obligations must be respected equally, which it found to be possible in the given case.$^{58}$ However, the tribunal did not discuss an adjustment of the host state's discretion corresponding to the severity of the potential human rights violations, i.e. the risk of depriving 10 million people of their right to health and water, the urgency for immediate action, and

\footnotetext{
${ }^{52}$ Azurix v. Argentine Republic, ICSID Case No. ARB/01/12, Award, 14 July 2006, para. 261. For a comprehensive analysis see: T.Meshel, "Human Rights in Investor-State Arbitration: The Human Right to Water", in: Journal of Int'l Dispute Settlement 6 (2015), 277-307.

${ }^{53}$ Kriebaum describes the argumentation as 'half-hearted' in: Kriebaum, "Foreign Investments \& Human Rights - The Actors and Their Different Roles", 7. When alluding to the argumentation by Argentina in this regard, the award refers to the expert opinion of Dr. Solomoni which is not public, see para 254.

${ }^{54}$ Azurix v. Argentine Republic, ICSID Case No. ARB/01/12, Award, 14 July 2006, para. 311.

${ }^{55}$ Siemens v. Argentina, Award, 6 February 2007, paras. 79, 121.

${ }^{56}$ Suez, Sociedad General de Aguas de Barcelona, S.A. and Vivendi Universal, S.A. v. Argentina, ICSID ARB/03/19, Decision on Liability, 30 July 2010, paras. 252, 256.

57 Ibid. para. 260.

${ }^{58}$ Ibid. para. 262.
} 
the state's minimum obligation to ensure affordable access to water at all times ${ }^{59}$, which could trigger a duty to act preventively and to respect a wider margin of appreciation on the side of the host state. Since such considerations and the precise scope of Argentina's human rights obligations were not discussed, it is hard to understand how the tribunal arrived at the conclusion that both obligations under the BIT as well as under human rights law - were not inconsistent.

In the most recent dispute involving the right to water, SAUR International v Argentina, Argentina explicitly argued that its 'most basic human rights obligation' - with constitutional hierarchy in the Argentine legal system - made it indispensable for Argentina to intervene in the investors' business; such human rights protection could not constitute an expropriation. ${ }^{60}$ When responding to the claimant's reference to the well-known dogma that the motives of a state act are indifferent for determining an expropriation, the tribunal responded by emphasizing that 'that human rights in general, and the right to water in particular, are one of the various sources that the tribunal should take into account to resolve the dispute'. ${ }^{61}$ However, it went on in stating that both obligations are compatible, since Argentina has the possibility to comply with its human rights obligations while compensating the investor. The precise counterbalancing of these two obligations was postponed to the decision on the merits. ${ }^{62}$

In the other Argentina crisis cases, the defense claims were first and foremost based on the 'necessity'clause in the US-Argentina BIT (which was interpreted in the light of customary international law ${ }^{63}$ or of GATT Article $\mathrm{XX}^{64}$ ) or on the 'exceptional circumstances', which should have influenced the 'legitimate expectations' of the investors. ${ }^{65}$ The precise criteria for a preclusion of liability differed depending on the legal interpretation of the necessity exception, for example as being based on the customary law rules on state responsibility (e.g. excluding recognition of 'necessity' of emergency measures if the state could have prevented the emergency situation) or on more flexible treaty exceptions providing for 'proportionality balancing' between the competing rights and legal values concerned. ${ }^{66}$ As explained in the Continental Casualty award ${ }^{67}$, interpreting BIT exceptions similar to the WTO jurisprudence on GATT Article XX enables arbitrators to 'balance' the competing rights and obligations more flexibly. ${ }^{68}$ Although the tribunals shied away from engaging into a discussion of any direct conflict between human rights and the BIT obligations at stake, the adoption of balancing methods from right-based constitutional law systems could promote convergence of human rights and international investment law. So far, tribunals did not seem to pay specific attention to the states' duty to mitigate and counteract threats for the human rights of populations suffering under an economic crisis. The jurisprudence by national Constitutional Courts in over-indebted EU member states

\footnotetext{
${ }^{59}$ Article 11(1) of the ICESCR, General Comment No. 15.

${ }^{60}$ SAUR International S.A. v. Argentine Republic, ICSID Case No. ARB/04/4, Decision on Jurisdiction and Liability, 6 June 2012 [only in French and Spanish], para. 328.

${ }^{61}$ Ibid. para. 330.

${ }^{62}$ Ibid. paras. $330-331$.

${ }^{63}$ CMS Gas Transmission Company v. Argentine Republic, ICSID Case No. ARB/01/8,
}

Award, 12 May 2005. Sempra Energy International v. The Argentine Republic, ICSID Case No. ARB/02/16, Award, 28 September 2007; Enron Corporation and Ponderosa Assets, L.P. v. Argentine Republic, ICSID Case No. ARB/01/3, Award, 22 May 2007.

${ }^{64}$ Continental Casualty v. Argentine Republic, ICSID Case No. ARB/03/9, Award, 5 September 2008.

${ }^{65}$ Total S.A. v. The Argentine Republic, ICSID Case No. ARB/04/01, Award (not public), 27 November 2013.

${ }^{66}$ Cf. Alec Stone Sweet and Giacinto della Cananea, Proportionality, "General Principles of Law, and Investor-State Arbitration : A Response to José Alvarez," New York University Journal of International Law and Politics 46 (2014): 911-954.

${ }^{67}$ E.g. Continental Casualty, Award, para. 199.

${ }^{68}$ Cf. also Alec Stone Sweet, "Investor-State Arbitration: Proportionality's New Frontier," 4 Law and Ethics of Human Rights 47(2010): 68-69. 
limiting the national rights of governments to curtail human rights protection in exchange for international debt arrangements illustrates that the relationships between investor rights, human rights and 'conditionality' of international financial assistance remain similarly controversial among creditor and debtor countries as among host states and foreign investors protected by BITs.

A further right to water case is Aguas del Tunari, S.A. v. Republic of Bolivia. The investors withdrew the claim in view of the continuous public protests (referred to by the international press as 'the water wars') that began after the increase of the water prices and accompanied the ICSID proceedings. ${ }^{69}$ Only the decision on jurisdiction was published, which rejected the objection that Aguas del Tunari was not eligible to invoke the Netherlands-Bolivia BIT as an allegedly de facto US-controlled corporation. ${ }^{70}$ A petition for amicus submission was rejected because the ICSID rules at that time did not foresee third party participation. ${ }^{71}$

In Veolia $v$ Egypt $^{72}$, Egypt had enacted legislation to increase minimum wages following the Arab Spring revolution without adjusting the concessions for waste disposal services as contractually guaranteed. ${ }^{73}$ Although the case is still pending and the documents are confidential, one can expect the main issue of the dispute to be the concept of legitimate expectations: Can an investor legitimately expect the continuity of severe human rights breaches even if backed up by a contract? Should it play a role if the government is corrupt or not accepted as the legitimate representative by the population? What can an investor legitimately expect when the international community is at the same time pressuring for increased labour standards? This case highlights common problems of many human rights violations in capital-importing, less-developed countries: First, host states very often tolerate or are complicit in human rights violations, for instance, by accepting low labour standards, promoting toxic products (e.g. tobacco consumption) and attracting foreign investors to benefit from such low protection standards. Second, especially developing states in transition may be compelled to initiate major legislative restructuring to limit adverse policy effects of previous authoritarian regimes.

Biwater Gauff $v$ Tanzania is a further case in which a host state invoked human rights in connection with a crisis as a justification for terminating the contract with a water company. Tanzania argued that the investor 'had created a real threat to public health and welfare'. However, with regards to its own human rights obligations, Tanzania seems to be more cautious when stating that 'it has a moral and perhaps even a legal obligation to act' ${ }^{74}$ The tribunal rejected the relevance of the right to water when assessing the legitimacy of the terminations of the contract; it mainly based its reasoning on the failures to meet the contractual requirements. .

The human right to health could potentially play a role in the pending investor-state disputes following Uruguay's and Australia tobacco control measures. ${ }^{75}$ So far, Philip Morris v Uruguay only passed the jurisdictional stage in which public health was discussed in context of a possible exclusion from

${ }^{69}$ Damon Vis-Dunbar and Luke Eric Peterson, "Bolivian water dispute settled, Bechtel forgoes compensation," Investment Treaty News (ITN), Jan. 20, 2006, http://www.iisd.org/pdf/2006/itn_jan20_2006.pdf, accessed July 9, 2015.

${ }^{70}$ Aguas del Tunari, S.A. v. Republic of Bolivia, ICSID Case No. ARB/02/3, Decision on Respondent's Objections to Jurisdiction, 21 October 2005, paras. 264 et .seq.

71 Letter to NGO regards Petition to Participate as amici curiae, 29 January 2003, http://www.italaw.com/cases/57\#sthash.wwd6obSl.dpuf accessed 09/07/2015.

${ }^{72}$ Veolia Propreté v. Arab Republic of Egypt, ICSID Case No. ARB/12/15, Notice of Arbitration, 25 June 2012.

$73 \mathrm{http} / / / \mathrm{www}$. iareporter.com/articles/french-company-veolia-launches-claim-against-egypt-over-terminatedwaste-contract-and-labor-wage-stabilization-promises/, accessed July 9, 2015.

${ }^{74}$ Biwater Gauff (Tanzania) Limited v. United Republic of Tanzania, ICSID Case No. ARB/05/22, Award (24 July 2008), paras. 436, 434.

${ }^{75}$ Philip Morris Brands Sàrl, Philip Morris Products S.A. and Abal Hermanos S.A. v. Oriental Republic of Uruguay ("Philip Morris v Uruguay"), ICSID Case No. ARB/10/7; Philip Morris Asia Limited v. The Commonwealth of Australia, UNCITRAL, PCA Case No. 2012-12 (in an unpublished decision of December 2015, this tribunal declined its jurisdiction for the complaint). 
jurisdiction in accordance with a provision allowing for prohibiting certain economic activities for reasons of public health (Article 2 of Uruguay-Switzerland BIT). ${ }^{76}$ Human rights argumentation was not invoked. However, in response to the request for an amicus brief submission by the World Health Organization (WHO) referring to the WHO's Framework Convention on Tobacco Control, the tribunal acknowledged the public interest involved in this case. ${ }^{77}$

To sum up this review of awards one may conclude that ISDS tribunals are rather reluctant to accept human rights based arguments and have not developed a coherent methodology for evaluating the human rights dimensions of investment disputes. Also host states are not eager to justify their measures in terms of their human rights obligations. The host state defenses discussed above were first and foremost grounded on contracts and arrangements underlying the investment (as in Biwater Gauff $v$ Tanzania) or on liability exceptions as informed by other international law sources (such as the customary rules on state responsibility) or by analogy to WTO jurisprudence on treaty exceptions (as in some of the Argentina crisis cases). Whether a host state justifies its regulatory measures by invoking public interests (like health protection) or human rights (like health rights) may not even change the judicial 'proportionality balancing'; for, the 'constitutional weight' of the governmental duty to protect public health depends on the human and constitutional rights of its citizens, just as the 'weight' of adversely affected investor rights may be influenced by human rights and corresponding 'corporate social responsibilities' of foreign investors. Paying more attention to the objective of a state measure and adjusting the proportionality test accordingly is an option already available for arbitrators for responding to human rights concerns raised by the disputing parties. However, human rights as a multilevel legal system protecting substantive entitlements continue to play an only marginal role in ISDS arbitration.

\section{Human Rights Introduced by Third Party Interveners}

Apart from human rights as investor rights, investment agreement and their enforcement by investment arbitration can have severe impacts on the human rights of the host state's population. As host states tend to justify their regulatory action by reference to public policy concerns, the participation of third parties is an important avenue for bringing in concrete human rights interests that otherwise risk being ignored. The following part will assess the practice of tribunals when confronted with human rights argumentation introduced by third party intervention and the impact thereof on judicial decision-making.

\section{Amicus curiae briefs}

There is an increasing number of third party interventions by NGOs and civil society groups as amici curiae. Such interveners often act as advocates for affected populations or communities in response to the reluctance of governments to introduce their own human rights duties into the investment dispute. The impact of the human rights argumentation by third party interveners can be assessed on two levels. First, the human rights argumentation may play an important role for the acceptance of an amicus submission when ISDS tribunals acknowledge that third parties' and public interests are at stake. Second, amici submissions may indeed promote the examination of human rights issues as part of the investment dispute. This part briefly outlines the development of third party interventions and surveys the most recent cases on the basis of these two questions.

\footnotetext{
${ }^{76}$ Philip Morris v Uruguay, paras. 151 et. seq.

${ }^{77}$ Philip Morris v Uruguay, Procedural Order No. 4, 24 March 2015, para. 30.
} 
Amicus curiae participation started with Methanex vs US in $2001 .^{78}$ The applicable NAFTA and UNCITRAL procedural rules did not include provisions on third party intervention. The tribunal nevertheless declared that it had the power to accept third party submissions in view of the public interests involved. ${ }^{79}$ Also the U.S. and Canada acknowledged the existence of considerable public interest. Meanwhile, in 2003, NAFTA's Free Trade Commission issued a statement in which amicus submissions were accepted subject to the discretion of each tribunal. ${ }^{80}$

With Suez/Vivendi, it was the first time that an arbitration tribunal working under the ICSID rules decided to accept participation of civil society organizations as amicus curiae even though the complaining companies had objected to it. ${ }^{81}$ It stated that the given case '.. involved matters of public interest of such a nature that have traditionally led courts and other tribunals to receive amicus submissions from suitable non-parties. ${ }^{, 82}$ At the same time, the tribunal emphasized that public interest is not a given in any ISDS case but only in this particular one since "the investment dispute centers around the water distribution and sewage systems of a large metropolitan area. ${ }^{83}$ In the decision on the merits, the tribunal explicitly responded to the human rights argumentation by Argentina and the amici; it made clear that it saw no incompatibility between the right to water and the BIT obligations and examined Argentina's plea of the defense of necessity against Article 25 of the Draft Articles on State Responsibility ${ }^{84}$ (codifying the customary rules on state responsibility) without giving any relevance to the human rights at stake. ${ }^{85}$

In UPS v Canada (2007) the tribunal made no reference to human rights in the acceptance of the amicus submission; it only referred to the submission when summarizing procedural history. ${ }^{86}$ The tribunals followed the argumentation of the amici by rejecting the parts of the claim that were based on labour rights. ${ }^{87}$ Nevertheless, there is no explicit reference to the amici nor to their arguments. Similarly, in Glamis Gold v USA the tribunal made no reference to human rights in the decision accepting the amicus submission. In Aguas del Tunari v Bolivia, the amicus submission was rejected; in Suez/Interaguas $v$ Argentina, the tribunal accepted the amicus submission on the ground that the operation of water and sanitary systems affects human rights. ${ }^{88}$ This connection also led the Biwater Gauff $v$ Tanzania tribunal to accept amicus participation. However, in the final award there is no reference made to the human rights raised in the submission.

James Harrison has convincingly inferred from this case law certain factors that apparently matter for acceptance. First, the subject matter of the case has to be of public interest. Secondly, the expertise and perspective of the amici must be expected to assist the tribunal. Thirdly, the amici participation is likely to lead to increased transparency and enhance legitimacy for ISDS in general and the case in

\footnotetext{
${ }^{78}$ Methanex Corporation v. US, UNCITRAL, Decision of the Tribunal on Petitions from Third Persons to intervene as “Amici Curiae", 15 January 2001.

${ }^{79}$ Ibid, para. 49.

${ }^{80}$ Statement of the Free Trade Commission on non-disputing party participation, 7 October 2003.

${ }^{81}$ Suez, Sociedad General de Aguas de Barcelona, S.A. and Vivendi Universal, S.A. v. Argentina, ICSID ARB/03/19, Order in Response to a Petition for Transparency and Participation as Amicus Curiae of May 19, 2005,

${ }^{82}$ Ibid. para 20.

${ }^{83}$ Ibid. para. 19.

84 Cf. J.Crawford, The International Law Commission's Articles on State Responsibility. Introduction, Text and Commentaries (Cambridge: CUP 2002).

85 Suez, Sociedad General de Aguas de Barcelona, S.A. and Vivendi Universal, S.A. v. Argentina, ICSID ARB/03/19, Decision on Liability, 30 July 2010, para. 262.

${ }^{86}$ United Parcel Services of America, Inc. v. Canada, UNCIRAL, Award on the Merits, 24 May 2007, para. 3.

${ }^{87}$ Cf. section II.1.2.

${ }^{88}$ Suez, Sociedad General de Aguas de Barcelona S.A., and InterAgua Servicios Integrales del Agua S.A. v. Argentina, ICSID Case No. ARB/03/17, Order in Response to a Petition for Participation as Amicus Curiae, 17 May 2006, para. 18.
} 
particular. ${ }^{89}$ As Harrison further pointed out, the rationale behind accepting third party intervention is hence not primarily to ensure legal remedies for affected individuals or communities; third party intervention is rather meant to increase the functionality of the tribunal. ${ }^{90}$

Harrison's appraisal is confirmed by subsequent case law. In Grandriver v USA, the National Chief of the Assembly of First Nations submitted an amicus curiae in support of the claimants. ${ }^{91}$ Since the letter was subsequently included in the claimant's reply, the tribunal did not have to decide upon a rejection of admission (e.g. due to an alleged lack of formality). ${ }^{92}$ Even though the letter was 'read and considered', its precise impact remains unclear. In accepting an amicus submission, the Philip Morris $v$ Uruguay tribunal also referred to the fact that 'granting the request would support the transparency of the proceeding and its acceptability by users at large. ${ }^{93}$

In Piero Foresti et al. v. South Africa, the petition to submit an amicus brief by the International Commission of Jurists ("ICJ") was accepted. ${ }^{94}$ The ICJ's petition mentions the broader public repercussions of this case: it concerned not only the legality and legitimacy of the Republic of SouthAfrica's legislation countering ramifications of the Apartheid regime, but also concrete international obligation of the home and the host state regarding non-discrimination, equality as well as the duty to international cooperation. ${ }^{95}$ It is noteworthy that - in the letter accepting the amicus brief submission the tribunal explicitly asked for feedback on the fairness and effectiveness of the third party participation. The proceedings were suspended and finally discontinued before the scheduled amicus submission could be filed. Further, most of the documents are not public, which makes it difficult to trace any impact of the amicus argumentation on the case. Still, the tribunal's request for feedback and dialogue shows its interest in improving the system of third party intervention. In contrast to this trend of acknowledging the benefits that amicus submission can entail for ISDS, there also have been cases such as Chevron v Ecuador (2010) ${ }^{96}$ and Pezold v Zimbabwe (2012) ${ }^{97}$ - in which the amicus participation was rejected, despite a considerable level of public debate on the human rights relevance and public protests.

It is worth analysing the grounds for rejection as formulated by the Pezold tribunal to shed some light onto how the third party intervention rules (i.e. Rule 37) of the ICSID Convention are interpreted. First of all, it deserves attention that the tribunal considered the petition although both parties rejected it. ${ }^{98}$

89 James Harrison, "Human Rights Arguments in Amicus Curiae Submissions: Promoting Social Justice?", in: P.M.Dupuy/F.Francioni/E.U.Petersmann (eds), Human Rights in International Investment Law and Arbitration (Oxford: OUP, 2010), 396, $404-405$.

${ }^{90}$ Ibid. 405.

${ }^{91}$ Grand River Enterprises Six Nations, Ltd., et al. v. United States of America, UNCITRAL, Amicus Curiae Submission of the Office of the National Chief of the Assembly of First Nations, 19 January, 2009, http://www.italaw.com/cases/510\#sthash.0n3vmJKm.dpuf.

${ }^{92}$ Grand River Enterprises Six Nations, Ltd., et al. v. United States of America, UNCITRAL, Award, 12 January 2013, para 60.

${ }^{93}$ Philip Morris v Uruguay, Procedural Order No. 4, 24 March 2015, para. 30.

${ }^{94}$ Petition for participation as a Non-disputing party pursuant to Article 41(3) of the ICSID Arbitration Rules by the International Commission of Jurists, 19 August, 2009, accessible via http://icj.wpengine.netdna-cdn.com/wpcontent/uploads/2012/06/SouthAfrica-foresti-advocacy-2001.pdf, accessed 9 July 2015.

${ }^{95}$ Ibid. para. 24

${ }^{96}$ Chevron Corporation and Texaco Petroleum Corporation v. The Republic of Ecuador, UNCITRAL,

PCA Case No. 2009-23, Submission of Amici, 5 November 2010. http://italaw.com/documents/Chevron_v_Ecuador_SubmissionOfAmici_5Nov2010.pdf.

${ }^{97}$ Bernhard von Pezold and others v. Republic of Zimbabwe, ICSID Case No. ARB/10/15, Procedural Order No. 2 , 26 June 2012.

${ }^{98}$ Ibid. para. 6 
Secondly, the tribunal rejected the petition on grounds of lack of independence of the petitioners. ${ }^{99}$ Thirdly, the tribunal stressed that it did not feel competent to interpret indigenous rights and did not find human rights to be applicable. ${ }^{100}$ Fourthly, the tribunal seems to indicate that the respondent state should raise the human rights issues at stake; it stated that 'the respondent has not yet filed a substantive pleading in these proceedings. However, it was afforded the opportunity to make observations on the Application, including any observations as to the perspective the Petitioners propose to bring to the factual and legal issues in these proceedings. ${ }^{101}$ This statement could imply that the tribunal saw the human rights relevance but was insecure how to precisely engage with arguments raised only by third parties. The tribunal's understanding of the independence requirement raises additional questions. To substantiate the need for this requirement, the tribunal cited Suez in which it was stated that 'the purpose of amicus submissions is to help the Tribunal to arrive at a correct decision by providing arguments, expertise and perspectives that the parties may not have provided or are not able to provide. The Tribunal will therefore only accept amicus submissions from persons who establish to the Tribunal's satisfaction that they have the expertise, experience, and independence to be of assistance in this case. ...'. In Pezold, the mere fact that the petitioners first tried to pursue their interests through domestic legislation and hence through government lobbying was held against them. It does not seem plausible to require that a government's stance as representative of its population diverges from civil society concerns or that there has not been any form of cooperation between the government and the civil society organization prior to the arbitration. As the tribunal in Methanex acknowledged, amici are advocates trying to assert certain interests and not independent experts. ${ }^{102}$

The analysis of the recent case law shows that there remain many uncertainties as to the conditions for acceptance of amici. There is no consistent practice and no clear guidance as to what role amici arguments should play in the judicial decision-making. Acceptance and impact of human rights arguments remain subject to the discretion of the arbitrators, which have so far failed to develop a consistent and transparent methodology. In most of the cases, the impact of the human rights arguments was left unclear. However, the review of the content of the amicus submission filed by NGO's, civil society organizations and human rights experts shows that third party intervention is a promising avenue for raising human rights concerns, especially those which were otherwise not represented in the proceedings but nevertheless considerably affected by the investment dispute. Reliance on the host state to bring in the relevant human rights issues may not be sufficient; for, human rights abuses are more likely to occur when tolerated by the state - either willingly or due to a lack of capacity. An increased acceptance of amicus curiae submissions and additional improvements of the system of third party intervention may be crucial for promoting a balanced human rights approach. A transparent and consistent methodology regarding the reasons for rejection, the role of the amici arguments in judicial decision-making as well as the procedures (such as access to information) is still missing.

Human rights introduced by the home state

When the procedural rules on third party intervention are phrased broadly, home states could in theory also intervene as 'third parties'. However, the aim of ISDS (i.e. the 'de-politicization' of commercial conflicts by excluding the investor's home state and substitution of diplomatic protection) explains the fact that states left out the possibility for home state intervention when concluding BITs. NAFTA

\footnotetext{
${ }^{99}$ Ibid. para. 56.

${ }^{100}$ Ibid. para. 57.

${ }^{101}$ Ibid. para. 59.

${ }^{102}$ Methanex Corporation v. United States of America, UNCITRAL, Decision of the Tribunal on Petitions from Third Persons to Intervene as "amici curiae, 15 January 2001, para. 38.
} 
Article 1128 remains an exception by allowing for home state intervention especially with respect to questions of interpretation. Under this provision, home states have argued in favour of sufficient regulatory scope of the host state and also for restrictive interpretations of investor rights. ${ }^{103}$ As home states are expected to protect and promote their national investors and increasingly acknowledge the transnational reach of their human rights obligations, it appears more and more conceivable that home states feel pressured to intervene in ISDS. Home states can, of course, also indirectly exert influence on arbitration proceedings. For example, the Italian Embassy in South Africa served a so-called aide memoire with regard to the Black Economic Empowerment legislation that led to the Foresti $v$ South Africa arbitration. ${ }^{104}$ Italy warned South Africa of the adverse effects this legislation will have on foreign investors and the likeliness of provoking a number of investment disputes. Italy was apparently not arguing in favour of promoting racial non-discrimination through South Africa's legislation. In sum, the introduction of human rights arguments into ISDS by the home state is possible but remains sporadic and cannot be relied on for promoting the human rights of the population inside the host state in a balanced and systemic way.

\section{Human Rights introduced by the Arbitrators ex officio}

Arbitrators have also referred to human rights ex officio, i.e. without having a dispute party referring to the specific argument. This has mainly been the case in the context of determining the scope of property rights and the existence of an expropriation. In Azurix, the tribunal sought guidance in the ECHR and corresponding case law. ${ }^{105}$ The tribunal in Tecmed $v$ Mexico referred to the case law of the ECtHR and the IACtHR for determining the existence of an expropriation and for stressing the legitimacy of distinguishing between nationals and non-nationals in this context. ${ }^{106}$ The human rights jurisprudence seems to have influenced the finding of the tribunal in that the denial to renew a permit to run a hazardous industrial waste landfill in response to public protests was seen as a political choice and as less legitimate in the context of an interference with the property rights of a non-national. In Saipem $v$ Banglades $h^{107}$, ECtHR case-law was cited to confirm the assertion that also immaterial rights can be property rights protected by IIL and also judicial acts may amount to illegal interference with property rights.

ISDS tribunal have occasionally resorted to HRL and jurisprudence to support the use of 'proportionality balancing' of investor rights with public interests as defined by human rights. ${ }^{108}$ In Mondev $v$ United States, the prohibition of the retrospective applicability of a new regulation was discussed without deciding whether a general prohibition of retroactive interferences into property rights is part of the applicable law in the NAFTA country concerned. ${ }^{109}$ When assessing Mondev's claim that the granting of a special governmental immunity for domestic tort law was in breach of NAFTA law, the tribunal turned to ECtHR case law by stating that it could provide guidance by

\footnotetext{
${ }^{103}$ Patrick Dumberry and Gabrielle Dumas-Aubin, "When and How Allegations of Human Rights Violations Can Be Raised in Investor-State Arbitration," Journal of World Investment \& Trade 13(3) (2012): 349, 368.

${ }^{104}$ Luke Eric Peterson, "South Africa mining arbitration sees another Amicus Curiae Intervention," Investment Arbitration Report, 2 September 2009, accessed July 6, 2015.

${ }^{105}$ Cf. section II.2.

${ }^{106}$ Téicas Medioambientales Tecmed, SA v Mexico, ICSID Case No ARB(AF)/00/2, Award, 29 May 2003, paras. 116, 122.

107 Saipem SpA v Bangladesh, ICSID Case No ARB/05/07, Decision on Jurisdiction and Recommendation on Provisional Measures, 21 March 2007, paras 130, 132.

${ }^{108}$ See, for instance, Tecmed $v$ Mexico, ICSID Case No ARB(AF)/00/2, Award, 29 May 2003, para. 122, with reference to ECtHR case law.

${ }^{109}$ Mondev International Ltd $\mathrm{v}$ United States of America, ICSID Case No ARB(AF)/99/2 (NAFTA), Award, 11 October 2002, para. 138 and 141-144.
} 
analogy. ${ }^{110}$ In Pheonix, the tribunal famously acknowledged that 'nobody would suggest that ICSID protection should be granted to investments made in violation of the most fundamental rules of protection of human rights, like investments in pursuance of torture or genocide or in support of slavery or trafficking of human organs. ${ }^{111}$

Also in cases in which human rights arguments were dismissed as not excluding liability, ISDS tribunals often referred back to human rights considerations when assessing compensation for damages. ${ }^{112}$ Yet, the occasional references by arbitrators to human rights for interpretative guidance in particular to human rights jurisprudence on property rights - do not follow a transparent, legal methodology. In light of the numerous dismissals of human rights arguments brought forward by amici and host states, this practice of sporadically referencing HRL and jurisprudence runs the risk of being perceived as selective, if not biased.

\section{Conclusions}

The ISDS practices discussed in Part II suggest that arbitrators prefer to leave it to the parties to decide on whether human rights arguments are raised either as independent claims or as interpretative guidance' for construing investment rules and principles (like FET). The discussion further indicates that arbitral tribunals are more open towards human rights arguments for clarifying principles of procedural fairness (e.g. access to justice, due process of law), legal methodology (e.g. 'proportionality balancing' of investor rights and other competing rights) and as a relevant factual context (e.g. in Veteran Petroleum Limited (Cyprus) v. Russia ). Where HRL and IIL reflect common principles, arbitral tribunals are more willing to accept the relevance of HRL. Property rights remain an exception to the risk of neglect of HRL in ISDS, for instance in view of the protection of property rights in regional HRL. A discussion of other substantive human rights (e.g. indigenous peoples rights or the right to water) is usually rejected due to lack of jurisdiction or the respective party's failure to substantiate its claim. Other interests protected by HRL are often not even identified. ISDS risks, thereby, adopting and perpetuating an one-sided human rights concept that is biased towards property rights and mainly rests on principles of fairness and procedural rights. The 'inalienable' and 'indivisible' nature of human rights and the rejection of legal hierarchies between civil, political, economic, social and cultural human rights might thus be ignored in IIL and ISDS. In addition to the protection of foreign investor rights as mandated by the underlying BIT, the adoption of a selective human rights approach will not lead to an adequate recognition of government duties to protect and fulfill human rights; it rather illustrates a prioritization of foreign investors' interests. The increasing civil society criticism of this structural bias of IIL continues to prompt increasing changes in the drafting of investment agreements that are likely to also encourage ISDS practices to balance investor rights more comprehensively with other constitutional rights of citizens and with corresponding governmental duties and 'social corporate responsibilities' to protect human and constitutional rights in non-discriminatory ways without unduly privileging foreign investor interests. ${ }^{113}$

\footnotetext{
${ }^{110}$ Ibid. para. 144 .

${ }^{111}$ Ibid. 78.

112 Clara Reiner and Christoph Schreuer, "Human Rights and International Investment Arbitration, 'Human Rights and International Investment Law and Arbitration," in: Human Rights in International Investment Law and Arbitration (note 89), $88-94$.

113 On recent reforms of IIL see: S.Hindelang/M.Krajewski (eds), Shifting Paradigms in International Investment Law (OUP 2016).
} 


\section{The Role of the Law: Methodology Questions regarding the Human Rights Dimensions in ISDS}

After having surveyed the current practice of ISDS tribunals of responding to human rights concerns in investment disputes, the different outcomes and approaches raise the question as to whether the reluctance towards 'human rights integration' is rooted in the treaty texts or in the judicial discretion of arbitrators. Part III outlines the possibilities (or even duties) of human rights integration into the dispute as they emerge from BIT texts and the customary rules of treaty interpretation. Part III first looks into the legal admissibility and relevance of human rights arguments which depends on the phrasing of the clauses on jurisdiction and the applicable law (section III.1). Against this background, it outlines the entry points in BITs and general international law through which human rights can become legally relevant for the settlement of investment disputes (section III.2).

\section{Jurisdictional clauses}

The jurisdictional clauses found in most investment agreements range from covering all disputes arising in connection with the investment or the investment agreement to specifically defined disputes. The scope of the jurisdictional clause is first and foremost relevant for the initiator of the dispute, in practice always the investor. Jurisdictional clauses stating that 'any dispute ... in connection with the investment' shall be covered, do not rule out claims going beyond BIT breaches. ${ }^{114}$ Nevertheless, as the comparative review of Biloune $v$ Ghana and Chevron $v$ Ecuador shows, much depends on the interpretation of the required 'relation' between the human rights at stake and the investment, and on what kind of rights the tribunal deems to be covered by the investment definition.

Investment tribunals are increasingly discussing whether their jurisdiction is only limited to lawful 'good faith' investments and investor claims. ${ }^{115}$ Following that line of reasoning, the jurisdictional clause can function as an entry point for human rights argumentation for the host state's defense so that investments made in violation of applicable HRL fall outside the ISDS jurisdiction.. ${ }^{116}$ However, the burden of proving the legal existence and violation by the investor of particular human rights violations lies with the host state. Even if the host state does not challenge the jurisdiction on human rights grounds, the tribunal has inherent powers to examine its jurisdiction ex officio or in response to human rights claims raised by adversely affected third parties.

For the admissibility of human rights arguments brought forward by amici curiae, the jurisdictional clause does not constitute the major hurdle. Instead, the requirements for the acceptance of third party interventions - as stipulated in the applicable procedural rules and established by ISDS jurisprudence need to be fulfilled. As discussed above, these requirements focus on whether (1) the human rights arguments reflect the public interests at stake in the investment dispute; (2) the expertise of the amicus curiae will assist the tribunal; (3) the admission of amici curiae will help to increase transparency and legitimacy of ISDS; and (4) whether the amici are independent representatives of public interests.

The remaining uncertainties revolving around the jurisdictional clause may explain the reluctance of ISDS tribunals to engage in discussions about the concrete human rights obligations of the host state and to integrate HRL as a substantive, right-based, constitutional law regime. Considering human rights as facts, or using vague language (such as being 'mindful' of the human rights at stake), seems to the preferred method of some tribunals in view of their limited jurisdiction and legal expertise in HRL.

\footnotetext{
${ }^{114}$ Vivendi, Decision on Annulment, 3 July 2002, para. 55.

115 Generally on good faith requirements of an investor: Abaclat and others (Case formerly known as Giovanna a Beccara and Others) v Argentine Republic, ICSID Case No ARB/07/5), Decision on Jurisdiction and Admissibility, 4 August 2011; Malicorp Limited v Arab Republic of Egypt, ICSID Case No ARB/08/18, Award, 7 February 2011.

${ }^{116}$ Cf. section II.3.1.
} 


\section{Applicable law}

The second requirement for a claim based on human rights to successfully pass the jurisdictional stage is that human rights law is part of the law applicable to the investment dispute. Investment agreements commonly refer to international law in their applicable law clauses. ${ }^{117}$ In accordance with Article 38 of Statute of the International Court of Justice, such a reference should be understood as incorporating international treaties, customary international law and general principles of law. Depending on the human rights obligations of the home and host states, the scope of HRL as integral part of the domestic law of the host state and of the international law obligations of the home and host states involved is likely to vary, apart from generally applicable jus cogens norms and the most fundamental human rights. Furthermore, human rights may be applicable when concessions or contracts between the host state and the investor include human rights clauses (e.g. in terms of human rights conditionality or corporate social responsibilities of the investor). Occasionally, investment tribunals have relied on applicable law restrictions to refuse the relevance of human rights arguments deployed by the host state or third parties. In Pezold v Zimbabwe, for instance, the relevance of indigenous peoples rights - which were invoked in the amicus brief - was rejected on grounds of non-applicability: The arbitral tribunals agreed in this regard with the claimants that the reference in the BIT to 'such rules of general international law as may be applicable' does 'not incorporate the universe of international law into the BITs or into disputes arising under the BITs' ${ }^{118}$ Such vague judicial reasoning entails considerable uncertainty as to the meaning of 'international law' in such 'applicable law' clauses.

\section{Entry points for human rights argumentation}

Even if the applicable jurisdiction clauses and applicable law clauses do not specifically refer to human rights, there are additional 'entry points' which complainants, respondents, third parties and arbitrators can use to introduce human rights arguments into the dispute.

\section{Legality of the investment}

As mentioned above, the legality of the investment has been frequently challenged by the defending host state in order to exclude jurisdiction or to deny an investor of the BIT's benefits based on the rationale that only lawful investments deserve international protection (so called 'clean hands' doctrine). ${ }^{119}$ It has been argued that the requirement of lawfulness should comprise compliance with HRL or at least with the most fundamental human rights. ${ }^{120}$ Such an argumentation can be grounded directly on BIT texts if they limit jurisdiction to investments 'in accordance with local laws' and HRL is part of the local law. It is contested whether such legality requirement is a continuous requirement or only applies to the establishment of the investment. ${ }^{121}$ According to the latter interpretation, post

117 Article 41 ICSID Convention, Article 1131 NAFTA, Article 36(6) ECT, Article 40(1) of 2004 Canada Model BIT; Article XI of 2007 Colombia Model BIT; Article 7(1) of 2008 Germany Model BIT.

${ }^{118}$ Pezold v. Republic of Zimbabwe, para. 57.

${ }^{119}$ For instance, in Fraport AG v. Philippines the tribunal rejected jurisdiction as the investment was not made in accordance with the host state's laws, see Fraport AG Frankfurt Airport Services Worldwide v. Philippines ICSID Case No. ARB/03/25, Award, 16 August 2007, para. 401 et seq.; In Inceysa Vallisoletana S.L. v. Republic of El Salvador, the investment was made fraudulently and hence in violation of the principle of good faith. Therefore, it did not deserve the protection of the respective BIT, see Inceysa Vallisoletana S.L. v. Republic of El Salvador, Award, 2 August 2006, paras. 238-244.

${ }^{120}$ Dumberry and Dumas-Aubin (note 103), 365.

${ }^{121}$ In favour of applying the legality requirement only to the admission phase: Mr. Saba Fakes v. Turkey, ICSID Case No. ARB/07/20, Award, 14 July 2010, para. 119. . 
establishment human rights violations would not affect the legality of an investment and the jurisdiction for ISDS.

Supporters of the 'clean-hands doctrine' acknowledge the requirement for an investment to be made in accordance with the law (and hence not to the detriment of the host state's human rights situation) even without the existence of a specific treaty provision. In Phoenix Action v. Czech Republic, , as already stated above, the tribunal noted that 'nobody would suggest that ICSID protection should be granted to investments made in violation of the most fundamental rules of protection of human rights, like investments in pursuance of torture or genocide or in support of slavery or trafficking of human organs. ${ }^{122}$ The tribunal concluded, that only investments made in accordance with local laws fall under the purview of BIT protection, even in the absence of an explicit 'in accordance with local law'clause in the BIT. ${ }^{123}$ The tribunal cited several cases in which it was stated that only bona fide investments deserve protection; the tribunal inferred from this jurisprudence that the 'clean-hands doctrine' was justified as a general principle of law. ${ }^{124}$ Hence, the bona fide requirement can be understood as placing certain duties on the investor going beyond observing the applicable local law such as compliance of the investment with general principles of international law. ${ }^{125}$ Also the practice of 'forum shopping' without the intent to actually engage in economic activity in the host state was considered to exclude good faith. ${ }^{126}$ Such an understanding leaves room for accepting other conduct of a similarly abusive character as grounds for excluding good faith. It would be in line with such rationale to argue that also an investment that is deliberately not contributing to economic and social development of the host state - and is by doing so thwarting the objective of the investment treaty does not deserve its protection. A similar argumentation was successful in Hesham Talaat M. AlWarraq v. Indonesia. ${ }^{127}$ The tribunal denied the benefits for the investor as he was breaching Indonesian laws and the respective BIT included an 'in accordance with local laws'-clause. However, it additionally stressed the fact that the investor's actions had also been to the detriment of the public interest which it found to 'fall[s] within the scope of application of the "clean hands" doctrine'. ${ }^{128}$. In Hamester v. Republic of Ghana, the 'clean hands' doctrine was also acknowledged as a general principle that exists independently of any treaty text. ${ }^{129}$ In terms of scope, one can argue that the principle of good faith also requires a certain standard of due diligence that may require some kind of human rights impact assessment; turning a blind eye on a high risk of contributing to human rights violations may not satisfy good faith requirements.

Still, the status of the 'clean-hands' doctrine as a general principle of law applicable in an investment dispute regardless of an 'in accordance with local/international law clause', the ratione temporis and ratione materiae of such a principle, and its relationship to human rights obligations remain

${ }^{122}$ Phoenix Action, Ltd. v. The Czech Republic, ICSID Case No. ARB/06/5, Award, 15 April 2009, para. 78.

${ }^{123}$ Ibid. paras 79, 100 et seq.

${ }^{124} \mathrm{Ibid}$. para. 100, with reference to supporting case-law, i.e. Plama Consortium Limited v. Bulgaria, 2008, ICSID Case No. ARB/03/24, Award, 27 August 2008,. paras. 138-139; Fraport AG Frankfurt Airport Services Worldwide v. Philippines, ICSID Case No. ARB/03/25, Award, 16 August 2007, para. 397, 402.

125 'The protection of international investment arbitration cannot be granted if such protection would run contrary to the general principles of international law', Ibid. para 106. 'This principle governs the relations between States, but also the legal rights and duties of those seeking to assert an international claim under a treaty.' Ibid. para. 107.

126 Ibid. para. 142.

${ }^{127}$ Hesham Talaat M. Al-Warraq v. Indonesia, UNCITRAL, Final Award, 15 December 2014, para 645 et seq.

128 Ibid. para. 647.

129 'An investment will not be protected if it has been created in violation of national or international principles of good faith; by way of corruption, fraud, or deceitful conduct; or if its creation itself constitutes a misuse of the system of international investment protection under the ICSID Convention ... These are general principles that exist independently of specific language to this effect in the Treaty'; Gustav F W Hamester GmbH \& Co KG v. Republic of Ghana, ICSID Case No. ARB/07/24, Award, 18 June 2010, paras 123, 124. 
contested. ${ }^{130}$ An investors' misconduct may also be taken into account in the calculation of damages. In the Yukos arbitration, the tax avoidance by the investor through establishment of sham companies in Russian tax havens was dismissed as an 'unclean hands' argument; but it led to a reduction of awarded damages. $^{131}$

\section{Treaty interpretation}

HRL can enter an investment dispute as a relevant legal context that should be taken into account when interpreting legal terms such as the definition of investment and the scope and effect of investment protection provisions such as the guarantees of FET. Article 31(3)(c) of the VCLT requires investment tribunals to interpret treaties taking into account 'any relevant rules of international law applicable in the relations between the parties' (so-called 'systemic integration method'). ${ }^{132}$ There is disagreement as to which human rights can be considered relevant rules in this regard. Certainly, the textual requirements are fulfilled when both parties to the BIT are parties to the same human rights convention, or both recognize relevant human rights as customary international law. In the case of multilateral treaties such as the ECT, there is disagreement on whether all parties of the multilateral investment treaty have to be parties of the human rights treaty, or only the parties to the investment dispute. Even if there is agreement on human right as relevant context of treaty interpretation, the effects of systemic integration on the interpretation of particular investment rules may remain contested. BIT commitments to human rights promotion or subsequent ratification and enforcement of human rights instruments may justify 'dynamic interpretation'. ${ }^{133}$ In view of the human rights core of property rights, judicial balancing of investor rights with human rights and related public policy objectives tends to be more important than claims of legal hierarchy (e.g. based on Article 103 of the UN Charter, jus cogens norms and the relevant treaty interpretation rules codified in Articles 53 and 64 VCLT). Governments increasingly renegotiate investment treaties or adopt interpretative statements so as to clarify the relevance of human rights for IIL. ${ }^{134}$ As all UN member states have human rights obligations, IIL must be presumed to be in conformity with the relevant human rights obligations. The presumption of legal coherence and the customary law requirement of interpreting treaties in conformity with 'principles of justice', including 'human rights and fundamental freedoms for all' (as codified in the Preamble and Article 31 VCLT), call for 'human rights friendly interpretations'.

\section{Preamble}

The wording of the preamble can enhance the acceptance and the relevance of human rights based argumentation. In Suez/InterAgua v Argentina, the tribunal acknowledged that the higher goal of the

${ }^{130}$ Dumberry and Dumas-Aubin (note 103), 362 et seq. with further references; For a thorough analysis of the different aspects, see A.D.Mitchell/M. Sornarajah,/Tania Voon, (eds), Good Faith and International Economic Law (Oxford: OUP, 2015).

${ }^{131}$ Yukos Universal Limited (Isle of Man) v. The Russian Federation, PCA Case No. AA 227, Final Award, 18. June 2014, para. 1633.

132 Cf. B.Simma/T.Kill, "Harmonizing Investment Protection and International Human Rights: First Steps Towards a Methodology," in: C.Binder et al. (eds), International Investment Law for the 21st Century: Essays in Honour of Christoph Schreuer, (OUP 2009), 678-707.

133 On dynamic interpretation method as one possible relation between human rights law and international investment law see: B.Simma, "Foreign Investment Arbitration: A Place for Human Rights?" International and Comparative Law Quarterly 60 (2011): 583. The tribunal in Tecmed v Mexico accepted dynamic interpretation, see Tecmed v Mexico, para. 116.

${ }^{134}$ Clear reference to human rights can be found in the new generation of BITs such as the Draft Norwegian Model BIT, Preamble, Articles 3, 8, 11, https://www.regjeringen.no/nb/dokumenter/horing---modell-forinvesteringsavtaler/id2411615/ accessed July 9, 2015. 
BIT is 'to further economic cooperation between them. The protection and promotion of foreign investment, while important to attaining that goal, are only a means to that end.' ${ }^{135}$ If the preamble recognizes increased economic prosperity and development or human rights promotion as the treaty's objective, Article 31(1),(2) VCLT requires the tribunals to interpret the treaty in that light. Uncertainties arise when the objective's role for interpretation is not stated clearly or several, contradicting objectives are listed. In Grand River $v$ USA, the tribunal rejected drawing guidance from the preamble. It gave precedence to the 'plain wording' of the BIT as it was convinced that other interpretations would amount to illegitimate alteration of the text. Additional uncertainties were caused by the fact that several diverse objectives were stipulated in the preamble of the given BIT. ${ }^{136}$

\section{Protection provisions}

Human rights can become relevant when applying and interpreting BIT protection provisions, in particular regarding 'full protection and security', FET and non-discrimination - both as limiting the scope of investor protection as well as informing the meaning of property and expropriation under IIL. As regards the former, host states have defended their measures allegedly infringing investor rights by pointing to their objective of protecting human rights and other public interests. As discussed above, ISDS tribunals have disagreed on the justificatory relevance of the purpose behind a state's act.

The assessment of the legitimate expectations of the investor - as a sub-element of FET ${ }^{137}$ and expropriation ${ }^{138}$ - has evolved into a prominent place for human rights consideration. The concept of the investors' legitimate expectation has been formulated in Tecmed and still remains the main point of reference. According to the interpretation in Tecmed, '[t]he foreign investor can [legitimately] expect [from] the host State to act in a consistent manner, free from ambiguity and totally transparently ... so that it may know beforehand any and all rules and regulations that will govern its investments. ${ }^{139}$ It would go beyond the scope of this paper to review all the relevant aspects discussed in the rich case law and literature on this topic. It suffices to point out that there is considerable agreement that the concept of legitimate expectation ensures predictability and transparency, but not a standstill of legislation. In this respect, human rights consideration can become relevant in many ways. The concept of legitimate expectation enables the accommodation of the specific human rights situation of developing countries. In that regard, it has been argued that the investor should take into account the specific economic and social circumstances in developing countries ${ }^{140}$, including a higher risk of changes of legislative environment, notably in a host country that is politically and socially

135 Suez, Sociedad General de Aguas de Barcelona S.A., and InterAgua Servicios Integrales del Agua S.A. v. Argentine Republic, ICSID Case No. ARB/03/17, Award, 30 July 2010, para. 200.

${ }^{136}$ Grand River Enterprises et al. v. United States of America, UNCITRAL (NAFTA), Award, 12 January 2011, paras. $69-$ 71.

137 Iona Knoll-Tudor, 'The Fair and Equitable Treatment Standard and Human Rights Norms', in Human Rights in International Investment Law and Arbitration (note 89), 339; Annika Wythes, 'Investor-State Arbitrations: Can the 'Fair and Equitable Treatment' Clause Consider International Human Rights Obligations?', Leiden Journal of International Law 23 (2010): 241-256.

138 Anna De Luca, "Indirect expropriations and regulatory takings: what role for the 'legitimate expectations' of foreign investors?," in: G.Sacerdoti/G. Pia Acconci/M.Valenti/A. De Luca (eds), General Interests of Host States in International Investment Law. Cambridge International Trade and Economic Law 13 (New York: Cambridge University Press, 2014).

${ }^{139}$ Tecnicas Medioambientales Tecmed SA v. Mexico, ICSID Case No ARB (AF)/00/2, Award, 29 May 2003, para. 154.

${ }^{140}$ Ursula Kriebaum, "Are investment treaty standards flexible enough to meet the needs of developing countries?," in: F.Baetens (ed), Investment Law within International Law: Integrationist Perspectives (Cambridge: CUP 2013). 
fragile. ${ }^{141}$ As Veolia $v$ Egypt shows, it is difficult to uphold legitimate expectations in a host country with continuous human rights breaches. ${ }^{142}$

When regulatory measures are under scrutiny by an investment tribunal and are measured in terms of legitimate expectations, the starting point should be that public law is changing. In fact, especially in many developing countries it must change. In terms of economic, social and cultural (ESC) rights, the duty of 'progressive realization' mandates states to constantly increase ESC standards with all resources available and change legislation to that effect. ${ }^{143}$ Investors should be aware of this need for legal change especially in cases in which the host state does not even fulfil the "minimum core obligations'. ${ }^{144}$ This anticipation should comprise the possibility of new general legislation (in order to fulfil the duty to respect) or concrete measures directed at the investor (if required so by the duty to protect). To anticipate such changes and assess the risks for its investment appropriately, certain due diligence measures or human rights impact assessments are advisable. Failures to do so can thus lead to the exclusion of investment protection. Furthermore, there is an abundance of international guidelines, codes of conducts and CSR mechanism that investors can turn to for information and guidance. ${ }^{145}$ These international standards may serve as a framework for arbitration tribunals when determining appropriate due diligence obligations.

Investors' failures thus can play a role when assessing the legitimate expectation. In Biwater Gauff v Tanzania, a FET breach was rejected because of the investors' poor performance in ensuring water supply for the host state's population. However, this failure was mainly relevant because it concerned a duty explicitly stipulated in a contract that was the basis for the investment. The tribunal did not assess the poor performance in the context of human rights as suggested by the amici. Similarly, in Total S.A. v Argentina, the investor's commercial calculations - which failed to include a proper assessment of the host country's legislation and the predictability of reforms - played a role in the assessment of a treaty breach. ${ }^{146}$

Furthermore, ISDS tribunals have resorted to 'proportionality balancing' as developed in human rights jurisprudence. ${ }^{147}$ In Total S.A. $v$ Argentina, the tribunal acknowledged the need to weigh the different interests at stake taking into consideration the broader context of the economic development of the host state. It imported the criteria for determining fairness from GATS while stating that - since both state parties are members of the GATS - it can legitimately serve as 'guidance'. ${ }^{148}$ The need for balancing the reasonable, regulatory discretion of host states and investor rights is widely accepted.

\footnotetext{
${ }^{141}$ Discussing a modified applicability of the protection provisions depending on the capability of the host state and whether state failures occur under normal or exceptional conditions: Pantechniki S.A. Contractors \& Engineers v. Republic of Albania, ICSID Case No. ARB/07/21, 30 July 2009, Award, IIII paras. 76-84. (.

142 Kriebaum, "Human Rights of the Population of the Host State in International Investment

Arbitration", JWIT10 (2009): 669

${ }^{143}$ Article 2(1) of ICESC.

${ }^{144}$ Cf. General Comment No. 3 para. 10, adopted by Committee on Economic Social and Cultural Rights (CESCR), 14 December 1990.

145 Instead of many see, UNHRC, Report of the Special Representative of the Secretary-General - Guiding Principles on Business and Human Rights: Implementing the United Nations "Protect, Respect and Remedy" Framework, U.N. Doc. A/HRC/17/31 (Mar. 21, 2011) (so called 'Ruggie principles'), Principle 17 with commentary. For a compilation of the most relevant documents see, Stephen Tully (ed)., International Documents on Corporate Responsibility,(Cheltenham: Edward Elgar Publishing, 2008).

${ }^{146}$ Total S.A. v. Argentine Republic, ICSID Case No. ARB/04/01, Decision on Liability, 27 December 2010, para. 124 with further reference to Maffezini v. Spain, ICSID Case No. ARB/97/7, Award on the Merits, 13 November 2000, para. 64..

147 Dupuy and Viñuales (note 4), at 29; N. Jansen Calamita, "International human rights and the interpretation of international investment treaties -- constitutional considerations", in Investment Law within International Law: Integrationist Perspectives (note 140); Stone Sweet/Cananea (note 66).

${ }^{148}$ Total S.A. v. Argentine Republic, ICSID Case No. ARB/04/01, Decision on Liability, 27 December 2010, para. 123.
} 
Proportionality as the appropriate weighing methodology has been both promoted ${ }^{149}$ and contested $^{150}$. Even if the legitimate public interest has a higher weight than the individual interests of foreign investors, it remains contested whether - and to what extent - such 'weighting' can justify a reduction of compensation protected under BITs. The 'proportionality' and 'weighting methodologies' applied in ISDS practices are often inadequately explained. ${ }^{151}$ The reasons for diverging applications of the proportionality method - when compared to rights-based constitutional law systems - are sometimes unclear.

\section{Quantification of damages}

If an investment tribunal considered a human rights based argument to be either outside its competence or not sufficiently substantiated to fully exclude investor protection, these evaluations are, nevertheless, at times reconsidered in the quantification of damages. Indeed, all of the stages of assessment outlined above can again play a role for the decision on the damages (e.g. due diligence, proportionality, clean-hands doctrine, bona fide considerations).

In RosInvestCo $v$ Russia, the tribunal did not deem the investor to have failed its due diligence obligations. Yet, the highly speculative nature of the investment was taken into account in assessing the quantum of compensation. ${ }^{152}$ In Yukos, the unlawful conduct of the investor did not exclude it from investor protection and thus from the tribunal's jurisdiction in the sense of the clean-hands doctrine; yet, it led to a mitigation of the compensation. ${ }^{153}$ It remains contested whether the 'internationalization' of foreign investor protection excludes a reduction of compensation in cases in which an indirect expropriation resulted from the host state's legitimate aim to comply with its human rights obligation. ${ }^{154}$ There are indeed many ways of adjusting the valuation model for compensation, for instance by taking into account investment risks (e.g. the anticipation of necessary and thus foreseeable legislative reforms) in the calculation of the 'fair market value'; in the absence of precise treaty regulations, much is left to the discretion of the arbitrators. ${ }^{155}$ From a human rights perspective, this lack of transparency and legal predictability as well as the 'negative discrimination' of domestic investors through procedural and substantive 'legal privileges' for foreign investors remain problematic.

\section{Conclusions}

Part I analyzed IIL and HRL as examples of dialectic legal fragmentation and progressive reintegration in view of the fact that all local, national and international legal systems - since the ancient Greek and Roman city republics 2500 years ago with their legal privileges for male property owners have evolved on the basis of protecting property rights, contractual freedoms and progressive, legal

\footnotetext{
${ }^{149}$ Stone Sweet, "Investor-State Arbitration: Proportionality's New Frontier” (note 68).

150 José E. Alvarez and Kathryn Khamsi, 'The Argentina Crisis and Foreign Investors: A Glimpse into the Heart of the International Investment Regime' The Yearbook on International Investment Law and Policy, 332 (2009): 441.

${ }^{151}$ For instance, in SAUR v Argentina, the tribunal recognized its task to balance investor rights and fundamental rights, yet failed to explicitly engage in balancing; cf. para. 332.

${ }^{152}$ RosInvestCo UK Ltd. v. The Russian Federation, SCC Arbitration V (079/2005), Final Award, 12 September 2010, paras $635,668$.

${ }^{153}$ Yukos Universal Limited (Isle of Man) v. The Russian Federation, PCA Case No. AA 227, Final Award, 18. June 2014, para. 1633.

154 Diane A. Desierto, Public Policy in International Economic Law: The ICESCR in Trade, Finance, and Investment(Oxford: Oxford University Press, 2015) 351.

155 Diane A. Desierto, "Conflict of Treaties, Interpretation, and Decision-Making on Human Rights and Investment during Economic Crisis." Transnational Dispute Management 10, no. 1 January 2013, 57 et seq accessed July 9, 2015.
} 
limitations of abuses of power politics (e.g. in terms of gender discrimination, slavery, 'market failures' and 'governance failures') through republican protection of public goods and constitutional rights.

Part II gave an empirical overview of the increasing references to human rights - by complainants, host states, third parties and arbitrators - in ISDS practices. Part III discussed more systematically the main IIL provisions that can be used as 'entry points' for human rights arguments, notably jurisdiction clauses, applicable law clauses, definitions of protected 'investments' in terms of their legal conformity with local and international laws, the customary rules of treaty interpretation, BIT Preamble references to human rights and other public interests, investment law protection standards (like 'full protection and security', FET, non-discrimination) and rules on awarding damages and quantification of compensation. Both Parts II and III revealed a lack of systematic methodology in the drafting of IIL and in its judicial interpretation and application, for instance depending on whether arbitrators perceive IIL and ISDS primarily from a commercial and private law perspective (e.g. in UNCITRAL arbitration), a public law perspective (e.g. recognizing HRL as integral part of the applicable domestic law of the host state), or from an international public law perspective (e.g. in ICSID arbitration based on bilateral and multilateral international treaties). Similar legal, procedural and systematic problems exist in the controversial relations between HRL and international trade law and adjudication ${ }^{156}$, in the limited number of investment disputes in the International Court of Justice that are initiated at the request of home states exercising diplomatic protection for foreign investments by their nationals ${ }^{157}$, and in commercial contract law and related commercial arbitration if the UN 'principles for responsible contracts' and 'corporate social responsibilities' are incorporated into longterm investment contracts, 'supply chain contracts', merger and acquisition agreements, joint ventures, licensing and franchise agreements. ${ }^{158}$ The customary rules of treaty interpretation, most IIL treaties and ISDS practices already offer many possibilities for interpreting IIL 'in conformity with the principles of justice and international law', including 'human rights and fundamental freedoms for all', as explicitly required by the Preamble and Article 31 of the VCLT. Yet, reconciling the diverse 'principles of justice' underlying the commercial and private law dimensions of IIL (e.g. in UNCITRAL arbitration and its enforcement through national courts), its transnational law dimensions (e.g. in concession contracts of foreign investors and host states), and in the public international law dimensions of IIL and related ISDS remains a challenging task and 'unfinished business'.

This contribution has argued that the different dimensions of HRL - e.g. as constitutional principles, cosmopolitan rights, judicial methodologies and corresponding governmental 'duties to respect, protect and fulfill inalienable and indivisible rights' and 'corporate social responsibilities' - can contribute to 'constitutionalizing' IIL and ISDS practices for the benefit of all citizens. As neither the foreign investor nor the government of the host state (notably in authoritarian and non-democratic regimes) may have interests in invoking HRL as constitutional constraints, HRL is often invoked in ISDS arbitration only through third party interventions or by arbitrators ex officio (e.g. in order to promote 'due process of law' and 'access to justice' for all interested and affected parties). The 'structural biases' of IIL (e.g. in terms of 'negative discrimination' against domestic investors) and of ISDS arbitration (e.g. in terms of procedural and substantive legal privileges for powerful foreign investors) reflect 'constitutional failures' and inadequate protection of human rights in many host states; the less the historical justification of BITs in terms of exporting 'principles of justice' compensating for inadequate legal and judicial protection of foreign investors inside less-developed, capital-importing host states continue to exist (e.g. in the context of transatlantic free trade and

\footnotetext{
${ }^{156}$ Cf. Ernst Ulrich Petersmann, "International Trade Law, Human Rights and the Customary International Law Rules on Treaty Interpretation," in The WTO and Human Rights, ed Sarah Joseph et al. , (Cambridge: CUP, 2009), 69-90.

${ }^{157}$ Cf. A.Vermeer-Künzli, Diallo: Between Diplomatic Protection and Human Rights, in: Journal of Int'l Dispute Settlement 4 (2013), 487-500.

${ }^{158}$ Cf. Ruggie/Sherman (note 6).
} 
investment agreements between EU and NAFTA countries), the more important becomes the task of 'merging' HRL and IIL through non-discriminatory, constitutional protection of domestic and foreign investors in domestic courts, with due respect for the legitimate reality of 'constitutional pluralism' and the diversity of national and international human rights regimes. This diversity of national and international HRL (e.g. in countries like the USA opposing regional and many UN human rights treaties) may also explain the reluctance of ISDS arbitrators to develop more systematic approaches to interpreting IIL in conformity with HRL. If neither the investor nor the host state refer to human rights, arbitrators may also prioritize their dispute settlement mandate by avoiding human rights arguments (e.g. on indigenous peoples rights, the human right to water) that risk to complicate compliance with the arbitral award and may trigger annulment proceedings criticizing judicial human right arguments. Ultimately, both ISDS and WTO dispute settlement bodies are economic courts with limited mandates rather than 'human rights courts' or 'constitutional courts' mandated to protect the constitutional rights of all citizens in the polity concerned. However, such limited mandates do not justify inconsistent and non-transparent human rights approaches that take into consideration only some human rights (e.g. jurisprudence related to property rights and procedural fairness) and disregard others (such as human rights to water and health protection if negatively impacted by foreign investments and invoked by host states as justification of investment regulations). ${ }^{159}$

\footnotetext{
${ }^{159}$ For a similar criticism see Meshel (note 52).
} 
